\title{
Modernising the English Court System - Time for a Gastric Band
}

\author{
Graham S McBain ${ }^{1}$ \\ ${ }^{1}$ Solicitor. MA (Cantab), LLB (Cantab), LLM (Harv). Open Scholar, Peterhouse, Cambridge. Fulbright Scholar, \\ Harvard Law School. UK \\ Correspondence: Graham S McBain, 21 Millmead Terrace, Guildford, Surrey GU2 4AT, UK. E-mail: \\ gsmcbain@aol.com
}

\author{
Received: March 11, 2013 Accepted: April 23, 2013 Online Published: August 30, 2013 \\ doi:10.5539/jpl.v6n3p17 URL: http://dx.doi.org/10.5539/jpl.v6n3p17
}

\begin{abstract}
There is a lot in the newspapers these days about human obesity and its detrimental effect on human health - as well as on the health budget. Indeed, statistics suggest that one in five adults in the United Kingdom is now clinically obese. What applies to human beings can also apply to human institutions and it is asserted that our legal system is clinically obese. It needs a gastric band. Why is our legal system clinically obese ? First, the volume of English primary - and subordinate - legislation is growing exponentially ${ }^{1}$ and, at this rate, it will start to become like that of the United States. Thus, it needs to be curtailed since the direct - and indirect - cost of all this is huge. ${ }^{2}$ Second, the present court system dates from the Victorian era and it creaks. Distinctly. In what way?
\end{abstract}

- There are too many obsolete courts;

- There are too many courts which - while not obsolete - should be merged with others;

- The court system is replete with anomalies and there are too many jurisdictional and procedural issues;

- The domestic court structure is a four tier system - when it should only be three tier;

- The complexity of the court system is such that it is not understood by lawyers -far less by the general public.

Need all this be so? The answer is a definite ' $n o$ '. What is needed in the $21^{\text {st }}$ century - in the Space Age - is a court system intelligible to the public and lawyers alike. One which is efficient and cost effective. One which is capable of processing cases more speedily. The taxpayer - who funds the court system and, indeed, the whole judicial system - deserves no less. A sense of modern economy - and not Victorian venerability - is what is required, especially when legislation has grown to alarming proportions. These days, with Britain in recession quite naturally - the Government is seeking to save money where it can. This includes the budget for the provision of courts and legal services. However, the Government should also focus on the actual structure of the courts. Here, major savings can be made, both in the short and the long term. ${ }^{3}$ Thus, this article considers the following courts:

- Judicial Committee of the Privy Council;

- Parliament;

- Court martial Court of Appeal;

- Ecclesiastical courts;

- High court;

- Crown court;

- County courts;

- Magistrates' courts;

\footnotetext{
${ }^{1}$ There are now some 3,000 general Acts, 30,000 Statutory Instruments, 26,000 local Acts and 11,000 private Acts, as well as a mass of EU directives.

${ }^{2}$ The direct cost results in large numbers of civil servants being employed in Central and Local government to process - and review - all this legislation, as well as to check it when new legislation is enacted. The indirect cost is the enormous cost to companies, private organisations and individuals in considering all this material in order to ensure compliance with the law.

${ }^{3}$ Financial savings would be made in terms of staff (judicial, administrative and civil servants), in buildings, in reducing the tiers of courts (thereby speeding up the judicial decision-making process) etc.
} 
- Obsolete courts.

\section{Judicial Committee of the Privy Council and Parliament}

Prior to considering the Judicial Committee of the Privy Council ('JCPC') - as well as Parliament when acting as a court - it is worthwhile to summarise their ambits:

- JCPC. This is the court of final appeal for UK overseas territories and Crown dependencies - as well as for a few Commonwealth countries and republics which have retained an appeal to the JCPC. This court of final appeal also hears - by virtue of legislation - a basket of rare appeals from the Church Commissioners, the Arches Court of Canterbury, the Chancery Court of York and overseas prize courts.4 The JCPC also hears: appeals from the Disciplinary Committee of the Royal College of Veterinary Surgeons, appeals against certain schemes of the Church Commissioners under the Pastoral Measure 1983 and disputes under the House of Commons Disqualification Act 1975. Finally, the sovereign may refer any matter to the JCPC, for 'consideration and report';

- Parliament. As well as being a political body, Parliament also comprises a judicial body. In practice, this latter role is (commendably) defunct, since mixing the two roles in the past proved to be like mixing fire and water and produced some remarkably unjust judgments. The judicial nature of Parliament is limited by history. By 1621, the House of Commons (the 'Commons') disclaimed both original, and appellate, jurisdiction. In the case of the House of Lords (the 'Lords'), after 1693, it no longer exercised original jurisdiction in civil matters and, in 2009, its appellate jurisdiction - both in civil and criminal matters - was transferred to the Supreme Court. However, the Commons can still (theoretically) act as accuser - and the Lords as judges - in the case of impeachment for 'high crimes and misdemeanours'; albeit the last instance was in 1806.5 The Lords can also try peerage cases. And both Commons and Lords retain a power to fine and imprison, on the basis that each comprises a court of record.

In this article, it is asserted the JCPC should be shorn of its statutory jurisdiction with most of it passing to the High Court. Also, of its jurisdiction to hear appeals from overseas territories and Crown colonies, this passing to the Supreme Court. Further, that Parliament should no longer act as a court.

- Acting as a court is not only not necessary today, it would appear to manifestly conflict with the European Convention on Human Rights (ECHR), part of English domestic law by virtue of the Human Rights Act 1998, article 6 of which provides that every person is entitled to a 'fair and public hearing within a reasonable time by an independent and impartial tribunal established by law.' Since the Lords no longer contains judges to advise them - and is manifestly a partial (political) body - it would seem, clearly, not to meet the requirement of being independent and impartial;

- Further, the Lords is a little out of practice acting as a court. The last time it heard a case of impeachment was in 1806 (the last successful case was in 1745). The last time a Bill of Attainder was passed was after the Jacobite rebellion in 1745. And the last time a Bill of Pains and Penalties was (unsuccessfully) sought was against Queen Caroline in 1820.

In conclusion, if the JCPC slims down - and Parliament divests itself of an outworn garment - the court system will be slimmer and trimmer. These matters are now considered in detail:

\section{Nature of the JCPC}

Commencing first with the JCPC, it may be noted there a number of legal, ${ }^{6}$ and historical, ${ }^{7}$ texts discussing it - mainly dating from the $19^{\text {th }}$ and century - as well as various articles. ${ }^{8}$ The JCPC also has its own website. ${ }^{9}$ The

\footnotetext{
${ }^{4}$ The JCPC also hears appeals from the Court of Admiralty of the Cinque Ports, albeit this court is now obsolete and has not sat since 1914.

${ }^{5}$ See generally, GS McBain (2011b), vol 85, pp 858-9 (note, in this article, the following typos were not picked up at the time of production:(a) p 819, line 1. The reference to (b) should be (c); (b) p 840, last line, the word 'fled' is missing after 'Vere'; (c) p 873, line 6 the reference to 'unserviceable' should be to 'serviceable'; (d) p 879, the Gunpowder plot should refer to James I, not II and the Monmouth rebellion to James II not to Charles II.

${ }^{6}$ Bentwich (1937); Burge (1841); Coote, (1868); Finlason (1878); Macpherson (1873); Macqueen (1842); Palmer (1831); Preston (1900); Salford \& Wheeler (1901); Palmer (1891); Wheeler (1893).

${ }^{7}$ Swinfen (1987); Howell (1970) (it contains a useful bibliography); Polden (2010), pp. 528-568.

${ }^{8}$ Haldane (1922) vol 1, p 153; Rankin, (1939), vol 7, pp 2-22; Smith (2008), vol 19 (3), pp. 551-74; Stevens (1964), vol 80, pp 343-69; Swinfen (1974), vol 90, pp 396-411.

${ }^{9}$ See website of the JCPC (google Judicial Committee of the Privy Council). See also an article on the website, C Smith, An Introduction to the Judicial Committee of the Privy Council.
} 
JCPC evolved out of the Privy Council ${ }^{10}$ on which there is also legal textual and historical material. ${ }^{11}$ Halsbury states, in respect of the legal jurisdiction of the JCPC:

The jurisdiction of the [JCPC] arose out of the prerogative right of the sovereign as the fountain head of all justice to entertain appeals from the courts in her dominions except where the right had been expressly delegated or surrendered. ${ }^{12}$ The sovereign exercised this jurisdiction through the council, which acted in an advisory capacity.

As Parliament developed its power and influence the High Court of Parliament became the final appellate tribunal for appeals from the United Kingdom but appeals from the overseas territories and from certain other courts still continued to lie to the sovereign in council. With the expansion of the British Empire in the eighteenth and nineteenth centuries this became a very substantial jurisdiction. These appeals came to be regulated by the Judicial Committee Act 1833 whereby all appeals were to be heard by a special committee of the Privy Council (the Judicial Committee) which would advise the Crown on the action to be taken. ${ }^{13}$ (wording divided for ease of reference)

This constitution of the JCPC is based on the Judicial Committee Act 1833, pursuant to which appeals formerly heard before a committee of the whole Privy Council were to be heard by the JCPC. ${ }^{14}$ The Act, section 1 (as amended) provides:

There shall be a committee of the Privy Council styled 'The Judicial Committee of the Privy Council.'

This Act also stipulates that the members of the JCPC shall consist of the following:

a. members of the Privy Council who hold (or have held) high judicial office; or

b. where another enactment provides for their membership. ${ }^{15}$

In practice, the JCPC comprises the members of the Supreme Court ${ }^{16}$ and there would seem to be no good reason - in modern times - for anyone else to be a member of the JCPC, nor be entitled to be. As for other pertinent matters:

- The JCPC sits in the same building as the Supreme Court. Until 2009, it sat in the council chamber in Downing Street; ${ }^{17}$

- The JCPC has a registrar and the practice - and procedure - of the court is laid down in legislation and various practice directions; ${ }^{18}$

- The JCPC reports to the sovereign (in the case of Brunei, the Sultan) in open court. ${ }^{19}$ It can take depositions from witnesses and it has power to re-examine them - albeit this power is rarely used; $;^{20}$

- The decisions of the JCPC are binding not only on the courts of the country from which the appeal came but also on the courts of other countries within its jurisdiction where a similar system of law operates; $;^{21}$

${ }^{10}$ See generally, Halsbury, Laws, vol 8(2), paras 521-6 \& vol 13 ( $5^{\text {th }}$ ed), para 701 et seq.

${ }^{11}$ Baldwin (1913); Beauchamp (1892); Dicey (1887); Fitzroy (1928); Leadam \& Baldwin (1918); Percy (1907); Tout (1914); Turner (1927-8); Adair (1924). See also Acts of the Privy Council New Series 1542-1604 (ed JR Dasent, 1890-1906, 32 vols) \& 1613-28 (1922-49, vols 33-43) and Proceedings and Ordinances of the Privy Council from 10 Richard II 1386 to 33 Henry VIII 1542 (ed H Nicholas, Record Commission, 7 vols, 1834-7).

${ }^{12}$ Hull \& Co v McKenna [1926] IR 402 at 404; AG for Ontario $v$ AG for Canada [1947] AC 127 at 145; $R$ v Bertrand (1867) LR 1 PC 520 at 530; Re Lord Bishop of Natal (1865) 3 Moo PCCNS 115 at 156. See also British Coal Corp v R [1935] AC 500 at 510. See also Howell, $\mathrm{n} 7$, p 3 .

${ }^{13}$ Halsbury, n 10, vol 10, para 403.

${ }^{14}$ Ibid, para 401.

15 Judicial Committee Act 1833, s 1(2) (as amended by the Constitutional Reform Act 2005). See also Halsbury, n 10, vol 10, para 401.

${ }^{16}$ Website, $\mathrm{n} 9$ 'Five judges normally sit to hear Commonwealth appeals, and three for other matters. These judges are usually Justices of The Supreme Court.'

${ }^{17}$ The JCPC usually sits in court no 3 of the Supreme Court.

${ }^{18}$ Halsbury, n 10, vol 10, para 416 et seq (which is dated). Also, website, n 9.

19 Judicial Committee Act 1833, s 3 'a report or recommendation thereon shall be made to his Majesty in Council for his decision thereon as heretofore, in the same manner and form as has been heretofore the custom with respect to matters referred by His Majesty to the whole of his privy council or a committee thereof (the nature of such report or recommendation being always stated in open court).'

${ }^{20}$ Smith, $\mathrm{n} 9$ '[under] the Appellate Jurisdiction Act 1833 s7 the Judicial Committee was empowered to take oral or written depositions from witnesses, and under s 8 it had the power to re-examine witnesses. In practice it rarely chose to exercise these powers, and would only do so in exceptional circumstances where the evidence had not been available in previous proceedings.' 
- When handling appeals from the Commonwealth, a few republics and Brunei, the JCPC is not acting as an English court as such. ${ }^{22}$

\section{Jurisdiction of the JCPC - Appeals from Abroad}

The extent of the JCPC's jurisdiction has considerably diminished as a result of the constitutional development of the British Commonwealth. ${ }^{23}$ Countries and territories which still refer appeals to the JCPC comprise the following: ${ }^{24}$

- Commonwealth ${ }^{25}$ Antigua \& Barbuda, Bahamas, Belize, Cook Islands and Niue (associated States of NZ), ${ }^{26}$ Grenada, Jamaica, St Christopher \& Nevis, St Lucia, St Vincent \& the Grenadines, Tuvalu;

- British Overseas Territories ('BOT'): Anguilla, Bermuda, British Virgin Islands, Cayman Islands, Falkland Islands, Gibraltar, Monserrat, Pitcairn Islands, St Helena and dependencies, Turks \& Caicos Islands;

- $\quad$ Republics: Trinidad \&Tobago, Dominica, Kiribati, Mauritius; ${ }^{27}$

- Sovereign Base Areas: Akrotiri and Dhekelia in Cyprus;

- Crown Dependencies: Jersey, Guernsey, Isle of Man; ${ }^{28}$

- $\quad$ Appeals to local Head of State: Brunei. ${ }^{29}$

As it is, the number of appeals to the JCPC is now low:

- In 2011, the JCPC heard just 37 petitions with only 8 being granted (in 2010, there were 46 petitions with only 19 being granted). ${ }^{30}$ Most of these petitions were from a very limited number of jurisdictions; ${ }^{31}$

${ }^{21}$ Halsbury, n 10, vol 10, para 404. See also Fautuma Binti Mohammed Bin Salim Bakhshuwen v Mohmaamed Bin Salim Bakhshuwen AC 1 .

${ }^{22}$ Smith, $\mathrm{n} 9$ 'While it must be understood that the [JCPC] is not an English court, and that its decisions form merely persuasive precedent in English law (see London Joint Stock Bank v Macmillan and Arthur [1918] AC 777), it would be foolish to treat it as immune to the changes, ideas, and influences at large in the English legal system.' This is not wholly correct. When acting as a domestic court of appeal, in the exercise of its statutory jurisdiction in various instances, the JCPC is acting as an English court.

${ }^{23}$ Halsbury, n 10, vol 10, para 403. Palmer, n 6, p 17 'no regular appeal [from the colonies to the JCPC] had been, in fact, presented from any of those colonies before February 1627-8' (the earliest colonies settled were Virginia, the Somer Islands and New England in the time of James I (1603-25). However, some authors contended that appeals from time to the JCPC did not occur until after the Restoration in 1660).'

${ }^{24}$ For the relevant Statutory Instruments and Acts, see Halsbury, n 10, vol 10, para 403.

${ }^{25}$ See Halsbury, n 10, vol 10, para 404 \& vol 3 ( $5^{\text {th }}$ ed), para 736 et seq. Website, n 9, summarises the appeal system. 'To bring an appeal to the [JCPC], you must have been granted leave by the lower court whose decision you are appealing. In the absence of leave, permission to appeal must be granted by the [JCPC]. In some cases there is an appeal as of right and a slightly different procedure applies. In civil cases, the lower court will generally grant you leave to appeal if the court is satisfied that your case raises a point of general public importance. In criminal cases, it is unusual for the lower court to have the power to grant leave unless your case raises questions of great and general importance, or there has been some grave violation of the principles of natural justice.

${ }^{26}$ Legislation enacted in New Zealand in October 2003 abolished appeals from New Zealand to the JCPC in respect of all cases heard by the Court of Appeal of New Zealand after the end of 2003. This legislation does not affect rights of appeal from the Cook Islands and Niue.

${ }^{27}$ In the case of Dominica, Kiribati (appeals lie only in constitutional cases affecting a Banaban), Mauritius and Trinidad \& Tobago, petitions are addressed to the JCPC and it decides them directly rather than advising the Crown. See Halsbury, n 10, vol 10, para 405. Website, n 9, 'from Kiribati an appeal lies only in cases where it is alleged that certain constitutional rights of any Banaban or of the Rabi Council have been or are likely to be infringed.'

${ }^{28}$ Website, $\mathrm{n} 9$, 'At the beginning of the fourteenth century, receivers were appointed to aid the dispensation of justice in Parliament. One group was appointed for Great Britain and Ireland, and one for the Channel Islands. Appeals from the Channel Islands became the first regular appellate business of the King's Council, now the [JCPC]. With the growth of the British empire, this business increased with appeals and petitions from the Royal Council, and Privy Council Committees were formed.' See also Palmer, n 6, p 17.

${ }^{29}$ Ibid, n 9, 'In civil cases only, an appeal lies to the [JCPC] from the Court of Appeal of Brunei to the Sultan and Yang di-Pertuan. By agreement between Her Majesty and the Sultan these appeals are heard by the [JCPC], whose opinion is reported to the Sultan instead of to Her Majesty.' See also Halsbury, n 10, vol 10, para 406.

${ }^{30}$ See website, $\mathrm{n} 9$.

${ }^{31}$ In particular, Jamaica, Mauritius and Trinidad \& Tobago. 
- If Jamaica terminates its system of appeal the JCPC will lose a substantial part of its caseload. Also, many jurisdictions have rarely been appealed from (in the case of the Sovereign Base Areas, there never appears to have been an appeal).

Appeals are invariably civil ones. As Halsbury notes, except where a question of interpretation of the constitution is involved, there is - in general - no right of appeal in criminal cases except by leave of the JCPC. 32

\section{JCPC - Statutory Jurisdictions}

The JCPC has also been given a number of statutory jurisdictions. However, these are very rarely invoked and, at the outset, one immediately asks - is it really necessary for one of the highest courts in the land to have to deal with matters which could be more easily dealt with by the High Court, which would also enable a system of appeal and be more cost effective?

\subsection{Appeal - Pastoral Measure 1983}

Halsbury states:

An appeal to her Majesty in Council against a pastoral scheme made by the Church Commissioners lies at the instance of any person who duly made written representations with respect to the scheme in draft, but only with the leave of the JCPC. If leave is granted, the appeal will be heard by the [JCPC] ${ }^{33}$ A statutory procedure is laid down for applying for leave to appeal, and for appeals. ${ }^{34}$

Thus, an appeal from a decision of the Church Commissioners on a pastoral scheme under the Pastoral Measure 1983 can be referred to the JCPC. Section 9(2) of the Measure states:

Any person who has duly made written representations with respect to the draft scheme may appeal to her Majesty in Council against the scheme or any provisions thereof, but only with the leave of the [JCPC].

However, such an appeal is rarely invoked and it may be noted that a similar scheme for a cathedral church under the Cathedrals Measure 1999 does not provide for an appeal to the JCPC. ${ }^{35}$ The last case referred to the JCPC appears to be The Revd A F B Cheesman and others $v$ Church Commissioners (judgment delivered on 17 March 1999).

It is asserted there is no need for such matters to be dealt with by the JCPC and that this jurisdiction should pass to the High Court - not least to enable a system of appeal.

\subsection{Appeals - Arches Court of Canterbury \& Chancery Court of York}

Appeals from these two ecclesiastical courts may be made on non-doctrinal matters. Halsbury states:

The Ecclesiastical Jurisdiction Measure 1963 confers on her Majesty in Council jurisdiction over appeals from judgments of the Arches Court of Canterbury and the Chancery Court of York given in causes of faculty not involving matter of doctrine, ritual or ceremonial, and these appeals are heard by the $[\mathrm{JCPC}]{ }^{36}$

\footnotetext{
${ }^{32}$ Halsbury, n 10, vol 10, para 408.

${ }^{33}$ Halsbury refers to the Pastoral Measure 1983, s 9(6).' If leave to appeal is granted, the [JCPC] shall hear the appeal, and the [JCPC] shall make a report thereon and may propose to Her Majesty in Council that the appeal should be allowed or dismissed or that the scheme should be returned to the Commissioners for reconsideration, and Her Majesty in Council may accordingly - (a) allow the appeal, in which case the scheme shall be of no effect, but without prejudice to the making and submission of a further scheme, or (b) dismiss the appeal and confirm the scheme, or (c) return the scheme to the Commissioners for reconsideration.'

${ }^{34}$ Halsbury, n 10, vol 10, para 411. The Pastoral Measure Act 1983, s 9(3) 'The provisions of Schedule 2 shall apply to applications for leave to appeal, and to appeals, to her Majesty in Council under this section.' See also Schedule 2 (appeals to the JCPC). See also Hargreaves v Church Comrs [1983] 2 AC 457 (it dealt with Pastoral Measure 1968 (No 1), s 8(2)).

${ }_{35}$ Ibid. The 1999 Measure repealed the Cathedrals Measure 1976, s 3(4). See also Halsbury, Statutes, vol 14.

${ }^{36}$ Ibid, para 411 . See also para 487 'No special rules have been made to govern the limited class of faculty appeals which now lie from the Arches Court of Canterbury and the Chancery Court of York [ie. under the Ecclesiastical Jurisdiction Measure 1963, s 8] and they are accordingly granted by the general procedure in the nineteenth century.'
} 
Thus, the Measure of 1963, s 7(1)(b) provides for the jurisdiction of the Arches Court of Canterbury and the Chancery Court of York ${ }^{37}$ and s 8 (1) provides that:

Her Majesty in Council has jurisdiction to hear and determine appeals from judgments of the Arches Court of Canterbury and the Chancery Court of York in proceedings which...those Courts have jurisdiction to entertain.

However, leave to appeal is required from the JCPC. ${ }^{38}$ Appeals under this measure would appear to be rare. A case in question is Rector and Churchwardens of the Parish of St Nicholas Acons v LCC (1928). ${ }^{39}$

It is asserted there is no need for such matters to be dealt with by the JCPC. This jurisdiction should pass to the High Court.

\subsection{Appeal - Admiralty Courts in British Possessions}

Halsbury states:

Appeals lie to the [JCPC] from admiralty courts in certain British possessions ... ${ }^{40}$

Thus, the Colonial Courts of Admiralty Act 1890, s 6(1) (still extant) provides: ${ }^{41}$

The appeal from the judgment of any court in a British possession in the exercise of the jurisdiction conferred by this Act, either where there is as of right no local appeal or after a decision on local appeal, lies to Her Majesty in Council. ${ }^{42}$

This Act only applies in respect of the BOT (formerly colonial territories) viz. Anguilla, Bermuda, British Virgin Islands, Caymans, Falklands, Gibraltar, Monserrat, Pitcairn Islands, St Helena and dependencies and the Turks \& Caicos islands. ${ }^{43}$ The Act does not apply to the Channel Islands, ${ }^{44}$ nor to the other territories referred to in 3. The Act also provided for appeals to the JCPC from Vice-Admiralty courts in these territories. However, these courts no longer exist. ${ }^{45}$ The occasions when appeals have been made on admiralty matters from BOT courts to the JCPC are very rare. Indeed, there appear to have been none in recent times. ${ }^{46}$ It is asserted these appeals in admiralty matters should be transferred to the High Court.

- There would not appear to be a legal problem with this. The BOT - being Crown possessions (cf. Commonwealth countries and republics) - there is nothing to prevent the Crown from transferring

\footnotetext{
37 'The Arches Court of Canterbury and the Chancery Court of York each have jurisdiction to hear and determine appeals from judgments, orders or decrees of consistory courts of dioceses within the provinces for which they are constituted respectively, being judgments, orders or decrees given, made or pronounced - (b) in causes of faculty not involving matter of doctrine, ritual or ceremonial.

${ }^{38}$ Section $8(2)$.

39 [1928] AC 469. See also Halsbury, n 10, vol 10, para 411. Ecclesiastical appeals have always been low. Howell, n 7, p 119 'ecclesiastical appeals constituted an insignificant part of the Judicial Committee's business after 1858.' Palmer, n 6, p 33 'Ecclesiastical and Admiralty appeals were first brought within the jurisdiction of the king in Council by an Act [2 \& 3 Will IV, c 92, Privy Council Appeals Act 1832] passed in the year immediately preceding the establishment of the Judicial Committee [in 1833]. This was done, as to the former...pursuant to a recommendation of the Royal Commissioners, appointed in 1830 to inquire into the Ecclesiastical Courts.' See also Ecclesiastical Courts. Report of the Archbishops' Commission (London, SPCK, 1954), p 25.

${ }^{40} \mathrm{Ibid}$, para 410. See also paras 490-500 'Procedure on appeal to the [JCPC] from courts of Admiralty or Vice-Admiralty in certain British possessions ... is regulated by the Judicial Committee (General Appellate Jurisdiction) Rules [1982/1676].' Halsbury also states 'The JCPC may, if it thinks fit, require the attendance of two nautical assessors on the hearing of Admiralty appeals. The preliminary procedure to be followed abroad is regulated by general rules or by special rules applying to courts in particular territories.'

${ }^{41}$ See also Richelieu and Ontario Navigation Co v SS Cape Breton (Owners) [1907] AC 112 and A-G for Ontario v A-G for Canada (1947) AC 127. The paucity of admiralty appeals to the JCPC up to 1909 may be seen from Beauchamp (1891 \& 1909).

${ }^{42}$ Section 6(2) provides 'Save as may be otherwise specially allowed in a particular case by her Majesty in Council, an appeal under this section shall not be allowed - (a) from any judgment not having the effect of a definite judgment unless the court appealed from has given leave for such appeal, nor (b) from any judgment unless the petition of appeal has been lodged within the time prescribed by rules, or if no time is prescribed within six months from the date of the judgment appealed against, or if leave to appeal has been given then from the date of such leave...'?

${ }^{43}$ See Halsbury, n 10, vol 13 ( $5^{\text {th }}$ ed), para $838 \&$ vol 93 ( $5^{\text {th }}$ ed), para 217. See also introductory note to Halsbury Statutes, n 35, vol 11(2).

${ }^{44}$ Colonial Courts of Admiralty Act, s 11 (1). The courts of the Channel islands have an independent admiralty jurisdiction; and a court of admiralty exists in the Isle of Man with jurisdiction almost identical to that of the Admiralty court of the High Court.

${ }^{45}$ Ibid, s 9(3) (any such courts existing prior to the Act were abolished in any case by s 17 of the Act). See also Halsbury, n 10 , vol 93 ( $5^{\text {th }}$ ed), para 217.

${ }^{46}$ I am grateful to the JCPC communications department for this information.
} 
jurisdiction from one English court to another, since the Crown is the fountainhead of all courts and it is only by way of historical anomaly the JCPC became the highest court of appeal from these places (the original reference being to the Privy Council):

- Transferring these admiralty appeals to the High Court will enable judgments to be given (as opposed to reports), will accord a right of further appeal and will help unify the court system. It will also simplify the procedure involved.

In conclusion, it is asserted this right of appeal from admiralty courts in BOT's to the JCPC should be transferred to the High Court. ${ }^{48}$.

\subsection{Appeal - Court of Admiralty of the Cinque Ports}

Halsbury states:

Appeals lie to the $[\mathrm{JCPC}]$ from ... the Court of Admiralty of the Cinque Ports... ${ }^{49}$

Once, there were a number of admiralty courts. This one has not sat since 1914 (and, rarely, prior to that) ${ }^{50}$ and it is the sole survivor of the ancient courts of admiralty.

- The jurisdiction of the Court of Admiralty of the Cinque Ports is laid down in the Cinque Ports Act 1821 and it extends (non-exclusively) from Shore Beacon (in Essex) to Redcliffe (near Seaford in Sussex). This court once sat at Sandwich or in the aisle of St James church in Dover. Its marshal carried a silver oar with the Lord Warden's cypher as a symbol;

- The office of marshal has merged with that of the admiralty judge of the Cinque Ports - which office is usually held by a high court judge who holds the appointment of an admiralty judge. Today, his only active duty is to take part in the election of the Lord Warden of the Cinque Ports.

A previous article has argued for the abolition of this court. ${ }^{51}$ It is asserted that the Court of Admiralty of the Cinque Ports should be abolished, its jurisdiction being transferred to the High Court.

\subsection{Appeal - Prize Courts}

Halsbury states:

In prize cases... appeals from all Admiralty courts, including the High Court, lie to the [JCPC]. ${ }^{52}$

Reference is made to the Naval Prize Act 1864, s 5 of which provides:

An appeal shall lie to her Majesty in Council from any order or decree of a prize court, as of right in case of a final decree, and in other cases with the leave of the court making the order or decree.

Section 6 states:

${ }^{47}$ Because the JCPC's position is anomalous (deriving from the Privy Council) many aspects of its procedure had to be set out in legislation. See for example the Judicial Committee Acts 1833, 1843 \& 1844. Transferring these overseas admiralty appeals to the High Court reflects the position from 1813-33 and indeed prior to that (between 1699-1813 there had been a tussle between the Privy Council's Appeals Committee and the High Court). See Howell, n 7, pp 34-5. As to the position from 1534, Carter (1944), p 108 'Appeals from the Admiral went in the fifteenth century to delegates appointed by the Crown, or special commissioners ad hoc. In 1534, [25 Hen VIII c 19] commissioners called Delegates of Appeals were appointed to hear appeals from the ecclesiastical and admiralty courts. Their powers were by $2 \& 3$ Will IV c 92 [1832], transferred to the King in Council; and by $3 \& 4$ Will IV c 41 [1833], the [JCPC] was formed to take all appeals which may be brought before the king in council.'

${ }^{48}$ It may be noted that, in England and Wales, the Municipal Corporations Act 1835 deprived all local courts of such admiralty jurisdiction they had (usually pursuant to a charter) excluding the Court of Admiralty of the Cinque Ports. Today, admiralty matters are administered by the High Court. The jurisdiction of the county court over admiralty matters was abolished in 1999, see Halsbury, n 10, vol 1(1), para 482.

${ }^{49}$ Halsbury, n 10, vol 10, para 410.

${ }^{50}$ For an appeal from the Court of Admiralty of the Cinque Ports, see The Clarisse (1856) 12 Moo PC (14 ER 940) 340. See also Halsbury, n 10 , vol $93\left(5^{\text {th }} \mathrm{ed}\right)$, para 213.

${ }^{51}$ McBain (2012).

${ }_{52}$ Naval Prize Act 1864, ss 5 \& 6. Rankin, n 8, p 8 'In time of war [the JCPC] is the Supreme Court of Prize. See also Halsbury, n 10, vol 10, para 410 \& vol 36(2), para 886. The Judicial Committee Act 1833, s 31 provides 'nothing herein contained shall be held to impeach or render void any treaty or engagement already entered into by or on behalf of His Majesty, or be taken to restrain His Majesty from acceding to any treaty, with any foreign prince, potentate, or power, in which treaty it shall be stipulated that any person or persons other than the said [JCPC] shall hear and finally adjudicate appeals from His Majesty's courts of admiralty in causes of prize; but that the judgments, decrees, and orders of such other person or persons so appointed by treaty shall be of the same force and effect of which they would respectively have been if this Act had not been passed.' This would appear to be obsolete. See also Halsbury, n 35, vol 11(2), introductory note. 
The $[\mathrm{JCPC}] \ldots$ shall have jurisdiction to hear and report on any such appeal, and may therein exercise all such powers as for the time being appertain to them in respect of appeals from any court of Admiralty jurisdiction, and all such powers as are under this Act vested in the High Court of Admiralty, and all such powers as were wont to be exercised by the Commissioners of Appeal in prize causes.

The jurisdiction of the JCPC to hear appeals from judgments or orders of the High Court, when acting as a prize court, was preserved by the Supreme Court Act 1981 (Senior Court Act 1981), s 16(2). ${ }^{53}$ This jurisdiction is anomalous since the jurisdiction of the JCPC to act as a court of appeal in admiralty matters was taken away by the Judicature Act of 1873. Prize is a term applied to a ship - or goods - captured by the maritime force of a belligerent at sea or seized in port. It has been extended - by legislation - to aircraft and to goods carried in them. ${ }^{54}$ The right of appeal to the JCPC will apply in respect of prize from the:

- High Court, Admiralty division; ${ }^{55}$

- Court of Admiralty of the Cinque Ports (albeit the latter is obsolete, see 4.4);

- Admiralty courts in BOT's (see 4.3). ${ }^{56}$

As it is, the possibility of prize cases occurring is very rare and there appear to have been none in recent times. ${ }^{57}$

- It is asserted the right of appeal from the High Court, admiralty division to the JCPC in respect of prize matters should be transferred to the Court of Appeal. ${ }^{58}$ Thus, an anomaly will be removed;

- Further, appeals on prize matters from the courts of BOT should also be transferred to the High Court - as has been recommended in respect of admiralty appeals (see 4.3). This would then correctly align the jurisdiction of admiralty and prize to the High Court, admiralty division which has the greatest expertise in such matters.

It is asserted that appeals from prize courts in BOT's should be to the High Court. And that appeals from the High Court in prize matters should be to the Court of Appeal - and not to the JCPC.

\subsection{House of Commons Disqualification Act 1975}

The JCPC may hear disputes under the House of Commons Disqualification Act 1975. Halsbury states:

Any person who claims that a person purporting to be a member of the House of Commons is disqualified by the House of Commons Disqualification Act 1975, or has been disqualified at any time since his election, may apply to her Majesty in Council for a declaration to that effect, and the application is referred to [the JCPC] in the same manner as an appeal from a court. ${ }^{59}$

This Act, $\mathrm{s} 7$, provides that:

(1) Any person who claims that a person purporting to be a member of the House of Commons is disqualified by this Act, or has been so disqualified at any time since his election, may apply to her Majesty in Council, in accordance with such rules as her Majesty in Council may prescribe, for a declaration to that effect.

(2) [The Judicial Committee Act 1833, s 3] ${ }^{60}$ shall apply to any application under this section as it applies to an appeal to her Majesty in Council from a court.

\footnotetext{
${ }^{53}$ Section 16(2) 'An appeal from a judgment or order of the High Court when acting as a prize court shall not be to the Court of Appeal, but shall be to Her Majesty in Council in accordance with the Prize Acts 1864 to 1944.' See also Halsbury, n 10, vol 10, paras 847 \& 886-7.

${ }^{54}$ Halsbury, n 10, vol 10, para 439 et seq.

${ }^{55}$ See also Naval Prize Act 1864, s 4 'The High Court of Admiralty shall have jurisdiction throughout her Majesty's dominions as a prize court.'

${ }^{56}$ Ibid, s 3, 'The High Court of Admiralty, and every court of Admiralty or of Vice-Admiralty, or other court exercising Admiralty jurisdiction in Her Majesty's dominions, for the time being authorized to take cognizance of and judicially proceed in matters of prize, shall be a prize court within the meaning of this Act. Every such court, other than the High Court of Admiralty, is comprised in the term "Vice-Admiralty prize court," when hereafter used in this Act.' See also Halsbury, n 10, vol 10, para 849.

${ }^{57}$ I am grateful to the JCPC communications department for the information. It may be noted that prize appeal jurisdiction was originally exercised by a Prize Commission of all the privy councillors and the judges of the common law courts. This was transferred to the JCPC by the Judicial Committee Act 1833. See Howell, n 7, pp 34-5, 58. Such appeals have always been low, Ibid, p 118 (also, some of the colonial Vice-Admiralty courts had no business in the period 1833-76).

${ }^{58}$ It may be noted that the Naval Prize Act 1864 does not apply to Commonwealth countries, republics and Brunei.

${ }^{59}$ Halsbury, n 10, vol 10 para 414. See also vol 34 para 614.

${ }^{60}$ Section 3 provides 'All appeals or complaints in the nature of appeals whatever, which either by virtue of this Act, or of any law, statute, or custom, may be brought before his Majesty or her Majesty in Council from or in respect of the determination, sentence, rule, or order of
} 
However, since this Act, s 7 (4), provides that issues of fact are to be tried by the High Court, ${ }^{61}$ there is no good reason why the High Court should not deal with the matter in toto. It would be more cost effective as well. There appears to have never been an appeal under this Act to the JCPC. ${ }^{62}$

It is asserted that all appeals under this Act should be transferred to the High Court.

\subsection{Appeal - Disciplinary Committee of the Royal College of Vets}

In the past, medical practitioners had a right of appeal in certain circumstances to the JCPC against various decisions of the Professional Conduct Committee, Committee on Professional Performance and the Health Committee of the General Medical Council ('GMC') or of the GMC. The National Health Service Reform and Health Care Professions Act 2002 replaced this with a right of appeal to the High Court. ${ }^{63}$ However, the Veterinary Surgeons Act 1966, s 17 still provides for a right of appeal to the JCPC from a disciplinary committee in relation to vets. ${ }^{64}$ An order in council lays down the procedure. ${ }^{65}$ The most recent case appears to have been Holmes v RCVS (judgment delivered on 20 December 2011).

It is asserted that it is anomalous for vets to have such a right of appeal - given the transfer of the appeal of other healthcare professionals to the High Court. Thus, appeals from vets should be transferred to the High Court as well.

\subsection{References by the Sovereign to the JCPC}

The Judicial Committee Act 1833, s 4 provides:

It shall be lawful for his Majesty to refer to the said [JCPC] for hearing or consideration any such other matters whatsoever as his Majesty shall think fit; and [the JCPC] shall thereupon hear or consider the same, and shall advise his Majesty thereon in manner aforesaid. ${ }^{66}$

The JCPC advises the sovereign the same way as on an appeal. ${ }^{67}$ Where a special reference is made it need not necessarily be carried out under this power, so that the JCPC advises judicially. Thus, the right exists to refer to a general committee of the Privy Council, including judicial members. ${ }^{68}$ Matters where this process has been utilised in the past referred to by Halsbury are the following:

- Colonial Matters, (a) conduct and powers of colonial judges in their office (1908); (b) jurisdiction of a colonial court to commit for contempt of court (1870); (c) professional behaviour and rights of practitioners in colonial courts (1868); (d) power of a governor of a colony to remit sentences for contempt of court (1893); (e) power of the Crown to annex a colony to another (1846); (f) status and jurisdiction of Church of England bishops in colonies (1865); $(\mathrm{g})$ boundary issues between colonies and dominions (1882);

\footnotetext{
any court, judge, or judicial officer, and all such appeals as are now pending and unheard, shall from and after the passing of this Act be referred by his Majesty to the [said JCPC], and such appeals, causes, and matters shall be heard by the [said JCPC], and a report or recommendation thereon shall be made to His Majesty for his decision thereon as heretofore, in the same manner and form as has been heretofore the custom with respect to matters referred by his Majesty to the whole of his privy council or a committee thereof (the nature of such report or recommendation being always stated in open court).'

${ }^{61}$ Where the constituency is in Scotland, then it is the Court of Session. If in Northern Ireland, then the High Court in Ireland.

${ }^{62}$ I am grateful to the JCPC for the information.

${ }^{63}$ See s 28. It also took away appeals to the JCPC in respect of dentists, opticians, osteopaths and chiropractors. See also Halsbury, n 10, vol 10 , paras $412-3$ \& 488-9.

${ }^{64}$ Section 17 'A person in relation to whom a direction has been given under the last foregoing section may, at any time within twenty-eight days from the date of service on him of the notice of the direction, appeal against the direction to her Majesty in Council in accordance with such rules as her Majesty in Council may by order provide for the purposes of this section; and the Judicial Committee Act 1833 shall apply in relation to the disciplinary committee as it applies in relation to such courts as are mentioned in section 3 of that Act.'

${ }_{65}$ Judicial Committee of the Privy Council (Veterinary Surgeons Rules) Order 1967/1150. See also Halsbury, n 10, vol 10, paras 413 \& 489.

${ }^{66}$ See also Halsbury, n 10, vol 10, para 415. 'Her Majesty may refer to the JCPC for hearing or consideration any other matter whatsoever as Her Majesty shall think fit, not necessarily arising from a judicial decision. This is called a special reference.' See also Howell, n 7, pp 40-2. For problems on the JCPC dealing with non-judicial matters and their not entering into policy matters, see Ibid, $\mathrm{p} 40$.

${ }^{67}$ Halsbury, n 10, vol 10, para 415. As Rankin notes, n 8, p 21 the report of the JCPC has no force of law as such. However, it is invariably acted on.

${ }^{68}$ D'Allain v Le Breton (1857) 11 Moo PC 64 (14 ER 619) at 70. Re Jersey States (1853) 9 Moo PCC 185 (14 ER 268) at 186 (mixed committee with law officers as assessors). Halsbury, n 10, vol 10, para 415.
} 
- Jersey \& Guernsey. (a) legislation in Jersey (1862); (b) privileges of the Jersey Bar (1866); (c) power of the executive in Guernsey(1844); (d) officers of the Royal Court of Guernsey (1869);

- Legislatures. (a) determination of a legislative council of questions of a member of its body (1887); (b) relative powers of the chambers of a legislature (1886);

- Land. (a) rights of the British South Africa Company to land in the former Southern Rhodesia (1919); (b) right to appoint a boundary commissioner to represent Northern Ireland on the Irish Boundary Commission (1924);

- House of Commons. (a) Eligibility of a person to sit and vote in the House of Commons (1951); (b) whether the House of Commons would be acting contrary to the Parliamentary Privilege Act 1770 in treating the issue of a writ against a member in respect of a speech or proceeding by him in Parliament as a breach of privilege (1958);

- $\quad$ Piracy. Law of piracy jure gentium (1934).

I have inserted the dates of the latest references to the JCPC cited by Halsbury. Most of the material is antiquated, being from Victorian and Edwardian times. Further, today, the majority of such matters would be handled by government departments or comprise the opinions of law officers. However, the JCPC has also advised recently. ${ }^{69}$ It may be noted that:

- This special reference system only applies to Crown Dependencies (ie. Isle of Man, Jersey and Guernsey) as well as to BOT's;

- It is anomalous in that it contains the right of the sovereign to remit to the JCPC any 'matters whatsoever as Her Majesty shall think fit' - and not just those arising from a judicial decision. This reflects the older status of the Privy Council as a political - as well as a judicial - body. This is not appropriate in modern times since there should be a proper separation of functions. Thus, today the JCPC should not be opining on political matters; any special reference should be restricted to "legal matters'.

It is asserted that such jurisdiction should be transferred to the Supreme Court (who, it may be noted, now hear devolution cases under the Constitutional Reform Act 2005, as opposed to the JCPC). The Supreme Court hears references from the sovereign on personal matters in any case. ${ }^{70}$

It is asserted that any special reference in matters affecting BOT's and Crown Dependencies should be transferred to the Supreme Court. It should also be limited to any 'legal' matter.

\section{Modernising the JCPC}

In 1871, Lord Hatherly LC sought to amalgamate the JCPC and the House of Lords (now the Supreme Court). ${ }^{71}$ A unified final court of appeal was also the wish of Lords Brougham, Westbury, Selborne, Cairns and Campbell. $^{72}$ This proposal failed. This is a pity since it would have streamlined the court system and reduced delays as well as bureaucracy. In the $21^{\text {st }}$ century, it is asserted there are a number of common sense modifications that should be made to the JCPC. This will recognise its diminished role and the fact that appeals from abroad will likely diminish further. ${ }^{73}$ These modifications will also help unify the court system, reduce bureaucracy, save costs, improve justice and make the JCPC more intelligible to lawyers and laymen. Thus, one would argue that the following changes should be made:

\footnotetext{
${ }^{69}$ Hearing on the Report of the Chief Justice of Gibraltar (advice delivered 12 November 2009). See also Hearing on the Report of the Tribunal to the Governor of The Cayman Islands - Madam Justice Levers (advice delivered 29 July 2010).

70 Thus, in 1717 and in 1772, the sovereign asked the judges of England to consider the nature of his paternal responsibilities. See Halsbury, n 10, vol 10, para 35. See also McBain (2011c), pp 95-118 at p 112 and Fortescue Reports, pp 401-40 (92 ER 909). Reference to the judges in such matters today would be to the Supreme Court.

${ }^{71}$ Smith, n 9, 'The second half of the nineteenth century witnessed sustained attempts to reform archaic appellate structures. Though the Judicature Commission of 1867 was not empowered to consider either the [JCPC] or that of the House of Lords, several influential reform initiatives were proposed at that time. In 1871, for example, Lord Chancellor Hatherley introduced a Bill which would have amalgamated the [JCPC] and House of Lords, and a select committee made similar proposals in the following year.'

${ }^{72}$ See generally Rankin, n 8. In particular, p 344, n 5 (Campbell) and p 348 (Westbury). See also Howell, n 7, p 69 'Meanwhile, [in 1874] Westbury, Cairns and The Times had come to share the view Brougham had expressed, forty years before, that the appellate jurisdiction of the House of Lords and the Privy Council should be merged into one joint Judicial Committee for the whole Empire.' See also p 221.

${ }^{73}$ It is likely appeals from Commonwealth countries, Brunei and various republics will decline in the not too distant future. This is a good thing since it will reflect the increasing expertise, and sophistication, of their own legal processes.
} 
- Composition of the JCPC. This should be limited to members of the Supreme Court. There is no need to include other members of the Privy Council and it avoids any suggestion of bias; ${ }^{74}$

- Transfer of Statutory Jurisdiction -Church \& Vets. Appeals from the Church Commissioners under the Pastoral Measures 1983 - as well as appeals from the Arches Court of Canterbury and the Chancery Court of York (in non-doctrinal faculty cases) - should be transferred to the High Court. This will permit a system of appeal and reflect the fact that equivalent cathedral measures have no right of appeal to the JCPC. It would also seem inappropriate that one of the highest courts in the land should have to deal with such matters. ${ }^{75}$ Appeals from the disciplinary Committee of the Royal College of Veterinary Surgeons should also be transferred to the High Court, as has occurred with other healthcare professionals - permitting appeals;

- Transfer of Statutory Jurisdiction - Admiralty. Appeals from BOT's admiralty courts (which are exceedingly rare) should also be to the High Court - including any prize appeals. And appeals from the High Court (Admiralty division) in prize should be to the Court of Appeal, and not to the JCPC - removing an anomaly (admiralty appeals to the JCPC ended in 1873). The Court of Admiralty of the Cinque Ports - which has not sat since 1914 - should be abolished.

- Transfer of Statutory Jurisdiction - House of Commons and Special References. Appeals under the House of Commons Disqualification Act 1975 should be to the High Court (or the Court of Session or High Court of Northern Ireland, as appropriate) - enabling a system of appeal (there have been none to the JCPC anyway). Special references by the sovereign of any matter to the JCPC for 'consideration and report' should be limited to 'any judicial matter'. Further, this jurisdiction should be transferred to the Supreme Court which already handles references from the sovereign in person in any case;

- $\quad$ Appeals from BOT's, Sovereign Base Areas and Crown Dependencies. These should all pass to the Supreme Court. As previously noted - being Crown territory - there would seem to be nothing to prevent the Crown from transferring jurisdiction since the Crown is the fountain of all courts and it is only by way of historical anomaly that the JCPC became the highest court of appeal from these places (the original reference being to the Privy Council). ${ }^{76}$ This will enable judgments to be issued - as opposed to reports - and it will help unify the court system. It will also avoid the cumbrous JCPC system in relation to its procedure (see below);

- Judicial Committee Act 1833. This should be repealed and most of its content - which relates to procedure - should be placed in a Statutory Instrument since the present material is antiquated and it does not need to be set out in a general Act. ${ }^{77}$ Other elderly Acts relating to the JCPC should also be repealed, all this material (excluding obsolete matter) being put in a Statutory Instrument; ${ }^{78}$

- Remainder. The JCPC would then only exercise jurisdiction over appeals from Commonwealth countries (Antigua \& Barbuda, Bahamas, Belize, Cook Islands and Niue, Grenada, Jamaica, St Christopher \& Nevis, St Lucia, St Vincent \& the Grenadines, Tuvalu) as well as the republics of

\footnotetext{
${ }^{74}$ Recruiting those in the Privy Council who hold high judicial office (or are retired) might be construed as seeking to obtain an outcome for the specific purpose of a case. It would seem better (as with the English court system in general) to limit the judges to those who sit generally and not to those who may have long been retired.

${ }^{75}$ How the JCPC came to exercise jurisdiction derives from historical events. Rankin, n 8, p 21 (writing in 1939), 'The jurisdiction of the king in council dates from the Act of Henry VIII passed in 1533 by which appeals to Rome were transferred to the king as Head of the Church of England. These were at first dealt with by a special commission of Delegates whose functions were transferred to his Majesty in Council in 1832. During Queen Victoria's reign many points of doctrine and ritual were brought before the [JCPC], but at the present time the work consists of appeals from sentences of the bishops' courts depriving clergyman of their livings for bad conduct, and also occasional appeals about a grant of a faculty. Upon Ecclesiastical appeals, three to five bishops attend as assessors.' See also Howell, n 7, pp 19-21, 34. For the caselaw prior to 1832, see Ecclesiastical Appeals 1533-1832 (1868). Also, Fuller (1865) and Joyce (1881).

${ }^{76}$ See also Rankin, n 8, p 8 appeals ended up with the JCPC 'from the position of the king as the fountain of all justice throughout his Dominions - a doctrine which has long been an axiom of the constitution though it was not so originally.' See also Nadan 's Case [1926] AC 482, 491 per Lord Cave 'In its origin such an application may have been no more than a petitiory appeal to the sovereign, as the fountain of justice for protection against an unjust administration of the law.' See also Judicial Committee Act 1844, s 1.

77 Thus, the Judicial Committee Act 1833, s 1 would be repealed, a new Act providing for only members of the Supreme Court to be members of the JCPC. Section 3 (special references) would also be dealt with in the new Act. See 4. All the other sections of the Judicial Committee Act 1833 would be inserted into a Statutory Instrument. Some of them can be repealed in any case.

78 Judicial Committee Acts 1843, 1844 \& 1915; Privy Council Registrar Act 1853, Judicial Committee Amendment Act 1895 and Appellate Jurisdiction Act 1908.
} 
Trinidad \& Tobago, Dominica, Kiribati, Mauritius. Also, Brunei. This list will likely further reduce in the near future. For example - if Jamaica ends its system of appeal - the likely number of cases referred to the JCPC will probably further deplete from the current 30 or so petitions to 20 or so. Consideration should also be given to ending appeals from Brunei, since they are so restricted in any case.

Legislation giving effect to all this could be very succinct. An Act could provide that the Supreme Court shall sit as the JCPC to hear appeals from certain countries, the same being listed in an SI, together with a simplified procedure. $^{79}$ Further reductions in bureaucracy and costs may be anticipated.

\section{Parliament Acting as a Court}

Parliament as well as being a political body is also a court - the High Court of Parliament. However, neither the Commons nor the Lords (whether singly or jointly), have made no attempt to exercise criminal - or civil jurisdiction for a long time. Further, one would assert that, today, they can no longer do so due to the ECHR, article 6 of which provides that every person is entitled to a:

fair and public hearing within a reasonable time by an independent and impartial tribunal established by law.

\subsection{House of Commons as a Court}

Halsbury states:

The appellate jurisdiction of the High Court of Parliament arises as an extension of the forum of the king's council. ${ }^{80}$ In 1399 the Commons declared by petition to the king (Henry IV), that the Commons had no role in this jurisdiction, which belongeth only to the king and the Lords. That this was the case was confirmed by the king's answer to the petition. That the jurisdiction was vested only in the Lords was also stated by all the judges in 1485. This position has not been questioned by either the courts or Parliament. The judicial jurisdiction to which these statements relate was both original and appellate. ${ }^{81}$

Halsbury also notes:

Although the House of Commons together with the sovereign and House of Lords forms the High Court of Parliament it is not strictly speaking a judicial body. Its original jurisdiction, which may be viewed as judicial, is confined to bills of attainder and of pains and penalties. In addition the House has jurisdiction over persons for committing any breach of the privileges of the House or any of its members. The House has long surrendered its judicial jurisdiction on petition, original and appellate. ${ }^{82}$

It seems clear - in a petition to Henry IV (1399-1413) recorded in the Rolls of Parliament - that the Commons accepted that it did not have criminal, or civil, jurisdiction - whether at first instance or on appeal. Thus, on the $3^{\text {rd }}$ November 1399, the House of Commons by a petition (I follow the translation of Stephen):

showed to the king, that judgments in parliament belong only to the king, and the lords, and not to the Commons unless the king, of his special grace, pleases to show them the judgment for their ease, that no record should be made in parliament against the Commons, that they are or shall be parties to any judgments given, or to be given afterwards in Parliament.

To which it was answered by the Archbishop of Canterbury by command of the king, that the Commons are petitioners and demanders [plaintiffs or accusers] and that the king and the lords from all time have had, and shall have by right judgment in parliament as the Commons have shown. But in making statutes, and granting aids and subsidies and such things for the common profit of the realm, the king's special will is to have their consent; and this order is to be observed for all time to come. ${ }^{83}$ (italics supplied and wording divided for ease of reference)

\footnotetext{
${ }^{79}$ In Victorian times much civil procedure (including Church of England matters) and criminal procedure was put in legislation when, today, in would be in subordinate legislation or rules, in order to enable easier amendment.

80 Halsbury refers to Pollock \& Maitland (1968), vol 1, pp 198-200 and to Holdsworth (2009), vol 1 pp 362-5.

${ }^{81}$ Halsbury, n 10, vol 10, para 359. See also para 351 'The House [of Commons] has long surrendered its judicial jurisdiction on petition, original and appellate'. See also.McBain, n 5, pp 861-2 \& pp 871-2.

82 Ibid, para 351.

${ }^{83}$ Stephen (1883), vol 1, p 155. See also Rolls of Parliament, iii 427 no 79 (3 November 1399).
} 
The reference to the judges in 1485 is to the decision of judges of the king's bench in Flourdew's Case (1486) ${ }^{84}$ Halsbury is not wholly correct in that the Commons did seek to exercise a criminal jurisdiction at first instance in cases such as those of Floyd (1621), ${ }^{85}$ Mitchell (1621) ${ }^{86}$ and Mompesson (1621) ${ }^{87}$ However, in the first case, the Lords took over judgment from the Commons and the latter two proceeded by way of impeachment since the Commons did not believe it had original jurisdiction in criminal matters.

In conclusion, it seems long established that the Commons has denied it has any criminal, or civil, jurisdiction whether original or appellate. However, it acts as accuser (plaintiff) in cases of impeachment and it also participates in the enactment of Bills of Attainder and of Pains and Penalties. These are discussed below - in the context of the criminal jurisdiction of the Lords.

\subsection{House of Lords as a Court}

Halsbury states:

The original jurisdiction of the House of Lords is that in impeachment and over peerage claims. In addition the House has jurisdiction over any breach of its privileges...Before 1693 the House, with increasing irregularity, considered and determined original judicial petitions. The House has neither received nor considered such a petition since that year. ${ }^{88}$

The issue of impeachment - as well as Bills of Attainder and Bills of Pains and Penalties - has been considered at length in another article.

- However, it is asserted the Lords cannot now act as a court since it no longer contains Law Lords to advise it on legal issues (they have decamped to the Supreme Court). Thus, it would not appear to meet the requirements of the ECHR, art 6, which requires courts to be independent and impartial, ${ }^{, 89}$

- Further, there is no need for the Lords to act as a court since the crime of 'high crimes and misdemeanours' is obsolete, the last case (the unsuccessful prosecution of Viscount Melville) having been in 1806 and the courts now having taken over the function of handling the criminal prosecution even of important people and politicians: ${ }^{90}$

- Bills of Attainder are also obsolete - not least since the death penalty for all offences was abolished in 1998. So too are Bills of Pains and Penalties. ${ }^{91}$

As well as these, the Lords can still exercise jurisdiction in respect of peerage claims. Thus, Halsbury states:

The House of Lords exercises an original jurisdiction in regard to matters of peerage. Proof of succession is not required for any purpose of inheritance, but it is required for inclusion on the Lord Chancellor's roll of the Lords, and on the Clerk of the Parliaments' register of candidates who wish to stand in a by election for the elected hereditary peers. From the time of Charles II [1660-85] all doubtful or contested claims to peerage have been referred to the House by the Crown not least because (until the passing of the House of Lords Act 1999) the determination of such a claim affected the membership of the House. The Crown acts on the recommendations of the House made by humble Address following a

\footnotetext{
${ }^{84}$ YB 1 Hen VII pl 5 fo 19b20a (1486). See also Seipp Index no 1486.034. Translations of many of the 22,000 cases in the Yearbooks have been published online by professor David Seipp in the form of an Index, see www.bu.edu/law/faculty/scholarship/yearbooks. See also Hemmant (1945), vol 64, pp 109-11 and Kiralfy (1957), pp 69-70.

${ }^{85} 2$ ST 1154 and McBain, n 5, pp 861-2 \& 871-2.

${ }^{86}$ McBain, n 5, pp 824.

${ }^{87}$ Ibid.

${ }^{88}$ Holdsworth, n 80, vol 1, pp 365-8. See also Bridgeman v Holt (1693) Shower PC 111 (1 ER 76). The Lords only seem to have claimed jurisdiction in Chancery appeals in 1621 (Sir John Bourchier's case). In 1675 attempts to assert it were violently opposed by the Commons who eventually desisted from their objection. In 1668 the Lords asserted a claim to be a court of first instance (Skinner v The East India Co). However, this was violently resisted by the Commons and, since then, the Lords have never acted as a court of first instance in civil cases. See Carter, n 47, p 47.

${ }^{89}$ See also McBain, n 5, p 864. Also, Janis (2008).

${ }^{90}$ Halsbury, n 10, vol 10, para 355. Also, McBain, n 5, pp 862-7 and Carter, n 47, pp 64-7.

${ }^{91}$ Ibid, para 354 (bills of attainder). Also, McBain, n 5, pp 867-71. Carter, n 47, p 67 'The Bill of Attainder, and the Bill of Pains and Penalties were nothing more, when passed, than Acts of Parliament for killing or otherwise punishing a man without trial.'
} 
resolution of the House made on report from the Committee for Privileges. The jurisdiction of the House extends to claims to Irish peerages, although peers of Ireland do not sit in the House. ${ }^{92}$

The House of Lords Act 1999 removed most of the hereditary peers (bar 92). Thus, claims will now be much more unlikely. Halsbury also notes that straightforward claims may be settled by the Crown on the report of the Attorney-General without reference to the Lords. ${ }^{93}$

It is asserted that any jurisdiction of the Lords to decide peerage claims should now pass to the High Court. This will permit a right of appeal and to comprise a less cumbrous mode of proceeding. ${ }^{94}$

\section{Parliament No Longer Acting as a Court}

It is asserted that Parliament should (and need) not act as a court any longer. This can be simply provided for in legislation. ${ }^{95}$

- The crime of 'high crimes and misdemeanours' should also be abolished - together with the criminal process of impeachment. Also, Bills of Attainder and Bills of Pains and Penalties; ${ }^{96}$

- The jurisdiction of the Lords in respect of peerage claims should pass to the High Court. This would enable judgment to be given, as well as a right of appeal. ${ }^{97}$

The ability of the Commons and Lords to act as a court of law should also be abolished; including their ability to fine and imprison. As it is - the last instance when Parliament exercised the right to imprison was the Commons in $1880{ }^{98}$ and the last time the Common imposed a fine was in 1666 (the Lords in 1801). ${ }^{99}$ Thus, abolition of these rights appertaining to a court of record would hardly be onerous. Abolition of the ability of the Commons and the Lords to act as a court of law would not affect their rights to: reprimand, admonish, expel or suspend their own members. 100

\section{JCPC and Parliament - Conclusion}

In conclusion, in respect of matters previously discussed, this article asserts that:

- All the jurisdiction of the JCPC should be transferred to the High Court or the Supreme Court save for its hearing of appeals from certain Commonwealth countries and republics (as well as Brunei);

- Parliament should no longer act as a court (including having the power to imprison and fine).

\section{Court Martial Appeal Court ${ }^{101}$}

The Court Martial Appeal Court ('CMAC') was established by the Court Martial (Appeals) Act 1951, which Act was replaced by one of the same name in $1968 .{ }^{102}$ The CMAC was established as a superior court of record. It hears appeals from courts martial in respect of the navy, army and air force. ${ }^{103}$ The process of appeal is as follows:

\footnotetext{
92 Ibid, para 357. For where membership of the Lords is not part of a peerage claim, see para 358. 'Where membership of the House is not concerned, the procedure on a claim to a peerage of England, Scotland, Great Britain or the United Kingdom is by way of petition to the Crown which the Crown refers to the House of Lords with a report on it by the Attorney General or the Lord Advocate. The House then refers the claim to the Committee of Privileges... The Committee [after coming to a conclusion] passes a resolution which it reports to the House; the House then agrees to a resolution which is submitted to the Crown.'

93 Ibid, para 357 (barony of Fitzwalter in 1953 is a case).

94 See also McBain, n 5, p 872.

95 See McBain, n 5, p 872, n 513.

${ }^{96}$ Ibid, p 872, n 514.

${ }^{97}$ Halsbury, n 10, vol 10, para 308 notes that (reports) decisions of the Committee of Privileges of the Lords are not judgments and are not binding in another claim.

98 Ibid, para 1022 'Each House of Parliament has power to commit to prison persons (including its own members) who offend against the privileges of the House concerned or who are considered to be in contempt, although the last time such a power was exercised was in 1880 , by the House of Commons.' The Committee of Privileges of the Commons in 1976 proposed that the power to imprison, as a penalty for contempt of the House, should be extinguished by legislation. Ibid, para 1024, n 3 and HC Paper 417 (1977-78).

99 Ibid, para 1023, n 5.

100 Ibid, paras 1025-7.

101 See generally Halsbury, n 10, vol 10, para 801.

102 Courts Martial (Appeals) Act 1968 (CMAA), s 1(1). See also Armed Forces Act 2006, s 272 (slightly altering the name of the court).

103 CMAA, s 1(1).
} 
- A person convicted by court martial court may - with leave of the CMAC - appeal to the CMAC against his conviction and against any sentence (not being a sentence fixed bv law) passed on him for the offence of which he was convicted. ${ }^{104}$ An appeal may also be brought - with leave of the CMAC - by a person against whom a fine has been imposed or a compensation order made. ${ }^{105}$ This right of appeal is normally subject to a person having first presented a petition to the Defence Council praying that his conviction (or sentence) be quashed; ${ }^{106}$

- The Judge Advocate of the Fleet, the Judge Advocate General or the Secretary of State for Defence (SSD) may - in certain circumstances - refer the finding of a court martial to the CMAC; ${ }^{107}$

- The SSD may refer the sentence passed on any person convicted by a courts martial to the CMAC. ${ }^{108}$

There is a further right of appeal (with leave) to the Supreme Court from the CMAC. ${ }^{109}$ The number of appeals the CMAC deals with annually is very small - being some 15 cases in 2011 (18 in 2010). The CMAC comprises:

- Ex-officio and ordinary judges of the Court of Appeal;

- Judges of the High Court as the Lord Chief Justice (LCJ) may nominate;

- Lords Commissioners of Justiciary as the Lord Justice General may nominate;

- Judges of the Supreme Court of Northern Ireland as the LCJ of Northern Ireland may nominate;

- Other persons of legal experience as the Lord Chancellor (LC) may appoint. ${ }^{110}$

The CMAC is summoned in accordance with directions given by the LCJ with the consent of the LC. ${ }^{11}$ It is duly constituted if it consists of an uneven number of judges, being - at least - three in number. ${ }^{112}$ The CMAC has power to determine any question necessary to be determined in order to do justice in the case before the court. ${ }^{113}$ The practice - and procedure - of the court is regulated by rules made by the LCJ with the approval of the $\mathrm{LC} .{ }^{114}$ The CMAC has a registrar and the $\mathrm{LC}$ appoints such other officers as are necessary. ${ }^{115}$

\section{Merging CMAC with the Court of Appeal}

One criticism of legal luminaries such as Lord Coke (his Institutes of the Laws of England were published between 1628-41), Hale CJ (his History of the Common Law of England was written in the 1640's -1660's but first published in 1713) and Blackstone (his Commentaries on the Laws of England were published between 1765-9) was that military law (which they called martial law) was outside the common law and that it was really no law at all, being based on the will of the sovereign. Thus, Blackstone (in 1765) stated:

For martial law, which is built upon no settled principles, but is entirely arbitrary in it's decisions is as sir Matthew Hale observes, in truth and reality no law, but something indulged, rather than allowed as a law: the necessity of order and discipline in an army is the other thing which can give it countenance;

\footnotetext{
${ }^{104}$ Ibid, s 8(1)(a). As Halsbury notes, there is a similar right of appeal against a finding by a court-martial of insanity or unfitness to stand trial. See ss 21(1) \& 24(1). For the application of the Act to prisoners of war see s 56, Sch 3.

105 Ibid, s $8(2)$.

${ }^{106}$ Ibid, s 8(2) \& (3). See also Morris v UK [2002] ECHR 38784/97 (European Court of Human Rights held that the system of administrative review provided for to be in breach of the European Convention on Human Rights (ECHR), art 6 which is part of English domestic law by virtue of the Human Rights Act 1998).

${ }^{107}$ CMAA, ss 34(1)-(3).

108 Ibid, s 34(4), (5).

${ }^{109}$ Halsbury, $\mathrm{n} 10$, para $801^{`}$ The decision of the court [CMAC] is normally final, but an appeal lies, with leave, to the [Supreme Court] at the instance of the accused or the Defence Council from any decision of the court, whether the court was sitting within or outside the United Kingdom. Leave to appeal may not be granted unless the court certifies that a point of law of general public importance is involved, and it appears to the court or the [Supreme Court], as the case may be, that the point is one which ought to be considered by the [Supreme Court].

${ }^{110}$ CMAA, s 2(1), 2(2). See also Halsbury, n 10, vol 10, para 802.

111 s 4(1).

112 s 5(1). One of whom must be at least a member of the court by virtue of his being an ex-officio or ordinary judge of the Court of Appeal, a judge of the High Court, a Lord Commissioner of Justiciary or a judge of the Supreme Court of Northern Ireland. See s 5 (4). Also, Halsbury, n 10, vol 10, para 802 .

113 Ibid, s 1(2).

114 s 49(1). See also Halsbury, n 10, vol 10, para 803.

115 Ibid, para 804.
} 
and therefore it ought not to be permitted in time of peace, when the king's courts are open for all persons to receive justice according to the law of the land. ${ }^{116}$

Blackstone referred to Hale CJ who stated, in his History of the Common Law:

But touching the business of martial law, these things are to be observed, viz. First, that in truth and reality it is not a law, but something indulged rather than allowed as a law; the necessity of government, order, and discipline in an army, is that only which can give those laws a countenance, quod enim necessitas cogit, defendit. ${ }^{117}$

These criticisms were directed at military law, pre-1688. After 1688, military law became more and more subject to legislation. By the $19^{\text {th }}$ century it was almost entirely legislative and it is today. Thus, military law has the sanction of Parliament. However, it still remains outside the general law applying to citizens and it imposes more obligations on military personnel by reason of their work than on the general public. This, however, should not prevent any court martial appeal not being tried by a normal civil court.

- It is asserted the CMAC should be merged with the Court of Appeal. This will further integrate military and civil law and well as ensure the application of impartial justice to the greatest extent possible; ${ }^{118}$

- The small number of cases the CMAC handles militates against the need for a separate court.

In conclusion, it is asserted the CMAC should merge with the Court of Appeal.

\section{Ecclesiastical Courts 119}

The church courts are State courts, since the Church of England is a State religion. ${ }^{120}$ However, they have separate jurisdictions ${ }^{121}$ - although there is a right of appeal in non-doctrinal matters to the JCPC. ${ }^{122}$

\subsection{Consistory \& Vicar-General's Courts}

The ecclesiastical courts of first instance were the consistory court and the archdeacon's court. ${ }^{123}$ The latter virtually ceased to function in the $19^{\text {th }}$ century. Today, consistory courts remain. Halsbury states:

For each diocese there is a court of the bishop of the diocese (to be called the consistory court of the diocese or, in the court of the diocese of Canterbury, the commissary court of that diocese) which has the original jurisdiction conferred on it by the Ecclesiastical Jurisdiction Measure $1963 .{ }^{124}$ [the '1963 Measure', ]

The consistory court of a diocese has original jurisdiction to hear and determine:

(i) proceedings on articles charging an offence under the 1963 Measure committed by a priest (or deacon) not being an offence involving a matter of doctrine, ritual or ceremonial ('doctrine');

(ii) a cause of faculty for any act relating to land in the diocese (or to anything on, or in, such land) being an act for the doing of which the decree of a faculty is requisite;

(iii) a faculty for the sale of books comprised in a library within the diocese; ${ }^{125}$

\footnotetext{
${ }^{116}$ Blackstone (1765-9), vol 1, p 400.

117 ie. it is to be defended/justified because necessity compels. See Hale (1971), p 26 (he appears to have written 'desendi' not 'defendit'.

However, the phase is normally taken to incorporate the latter word).

118 This would not prevent a CMAC judge(s) becoming a judge of the Court of Appeal.

119 See generally, Halsbury, n 10, vol 10, para 805. See also Moore \& Briden (1985) and texts cited in Sweet \& Maxwell (1957). It lists English legal texts up to 1954. See in particular, vol 1, pp 183-9. See also Coote (1847); Paget (1854); Edwards (1853); Report of the Commissioners on the Constitution and Workings of the Ecclesiastical Courts (Eyre \& Spottiswoode, 1883); Ecclesiastical Courts. Report of the Archbishops' Commission (London, SPCK, 1954) ('1954 Report')(a useful work) and Hill (2007). See also Carter, n 47, ch 21.

${ }^{120}$ Moore \& Briden, n 119, p 130 'the church's courts are courts of the State and the State's courts are courts of the church.'

${ }_{121}$ As Moore points out, n 119, p 131, prior to 1072, the shire and hundred courts exercised both temporal and ecclesiastical jurisdiction. After that, they had separate jurisdictions - although the two are now converging again. See also 1954 Report, n 119, p 1 and Stubbs (1966), pp 99-100 (Ordinance of William I separating the spiritual and temporal courts).

${ }_{122}$ Halsbury, n 10, vol 10, para 805. See also Moore, n 119, p 132 and 1954 Report, n 119, pp 23, 44-6.

${ }^{123}$ Also, called the Archdeaconary Court. See also Tristam (1893).

${ }^{124}$ Halsbury, n 10, para 805. See also 1963 Measure, s 1(1).

${ }^{125}$ This is a library to which the Parochial Libraries Act 1708 applies. This Act is, in many respects, obsolete.
} 
(iv) proceedings for an injunction (or restoration order) under the Care of Churches and Ecclesiastical Jurisdiction Measure 1991 (the '1991 Measure');

(v) proceedings on any jus patronatus (ie. to determine which of two claimants has the right to present to a living) awarded by the bishop of the diocese;

(vi) certain proceedings under the Pluralities Act 1838;

(vii) any other proceedings it had jurisdiction to hear prior to the 1963 Measure. ${ }^{126}$

For the provinces of Canterbury and York there is also a vicar-general's court with original jurisdiction to hear and determine - in respect of every cathedral church in the province - proceedings instituted on behalf of a bishop for an injunction (or a restoration order) under legislation relating to the care of cathedrals. ${ }^{127}$ In practice, today,

- In civil matters, consistory courts mainly handle faculty decisions concerning churchyards and church buildings and the court is usually a 'paper one' - the chancellor simply deciding the matter and a formal court with witnesses not being convened;

- On the criminal side, the court deals with the misconduct (non-doctrinal) of clergy under the Clergy Discipline Act 1892 . However, such cases are rare; there seem to have been only 3 since 1963 - the last in 1995 with the person being acquitted of sexual misconduct.

Given this, consideration should be given to abolishing consistory courts - as well as vicar-general's courts and Archdeaconary courts (the latter is obsolete but does not appear to have been formally abolished). On the civil side, provision should be made for all matters to be decided by a chancellor - with a right of appeal to the High Court. On the criminal side, the jurisdiction of the consistory court under the Clergy Discipline Act 1892 should be transferred to the High Court.

\subsection{Provincial Courts}

Halsbury states:

For each of the provinces of Canterbury and York there is a court of the archbishop of the province (to be called, in the case of the court for the province of Canterbury, the Arches Court of Canterbury ${ }^{128}$ and, in the case of the province of York, the Chancery Court of York) ${ }^{129}$ which has appellate jurisdiction conferred on it by the 1963 Measure. ${ }^{130}$

Of the judges of the Arches and Chancery courts, one must be a judge of both courts. ${ }^{131}$ The provincial courts each have jurisdiction to hear and determine:

(i) appeals from judgments, orders or decrees of consistory courts being those referred to in (i), (vi) \& (vii) in (a) above;

(ii) causes of faculty involving a matter of doctrine; or

(iii) proceedings for an injunction under the 1991 Measure (or for a restoration order under the same);

(iv) interlocutory orders of the consistory courts in causes of faculty involving doctrine;

(v) appeals from judgments, orders or decrees of the Vicar-General's courts.

An appeal which either of those courts has jurisdiction to entertain lies - in a civil suit - with leave at the instance of any party to the proceedings and - in a criminal suit - at the instance of any party to the proceedings on a question of law and the defendant on a question of fact. ${ }^{132}$ From the provincial court, appeal lay to Rome. However, with the abolition of this by the Ecclesiastical Appeals Act 1532, a final appeal lay to the sovereign in Chancery, ${ }^{133}$ with

${ }^{126}$ Halsbury, n 10, vol 10, para 807.

1271963 Measure, s 6. See also Halsbury, n 10, vol 10, para 805 and the Care of Cathedrals (Supplementary Provisions) Measure 1994, ss 4,5 .

${ }^{128}$ Moore, n 119, p 132, 'In Canterbury this became known as the Court of the Arches from the fact that it usually sat in the arched crypt of the church of St Mary le Bow in the City of London, where it still at times sits.' See also Halsbury, n 10, vol 10, para 806.

${ }^{129}$ Its judge was called the auditor.

${ }^{130}$ Halsbury, n 10, vol 10, para 805. See also 1963 Measure, s 1(2)(a). Also, 1954 Report, n 119, pp 8-9.

${ }^{131}$ Ibid, para 806. He is referred to as the Dean of the Arches and Auditor.

132 Ibid.

${ }^{133}$ Submission of the Clergy Act 1533. 
the jurisdiction being (in fact) exercised by a body called the Commission of Delegates, the actual court becoming known as the Court of Delegates. In 1832, appellate jurisdiction was transferred to the JCPC. ${ }^{134}$

If consistory courts were abolished, one would assert that provincial courts should also be abolished. Instead, an Ecclesiastical Court would handle any doctrinal matters - with a right of appeal to an Ecclesiastical Court of Appeal (as a final court of appeal). It may be anticipated that such courts would rarely sit.

\subsection{Court of Ecclesiastical Causes Reserved (CECR) and Commissions}

Halsbury states:

there is also a court (to be called the Court of Ecclesiastical Causes Reserved) which has the original and appellate jurisdiction conferred on it by that [ie. the 1963] Measure. ${ }^{135}$

This court must be constituted of 5 judges appointed by the Queen. Two must be persons who hold (or have held) high judicial office and who make a declaration that they are communicants and three must be persons who are (or have been) diocesan bishops. ${ }^{136}$ This court has original jurisdiction to hear and determine:

(i) proceedings upon articles charging an offence against the laws ecclesiastical involving a matter of doctrine committed by a priest (or deacon) or by an archbishop (or bishop) who was a diocesan or a suffragan bishop commissioned by the same;

(ii) suits of duplex querela (ie. suits to test the right of a bishop to refuse to institute a presentee);

(iii) appeals from judgments, orders or decrees of consistory courts in matters of doctrine. ${ }^{137}$

Commissions may be appointed in each province with original jurisdiction to try bishops (and archbishops) for ecclesiastical offences. ${ }^{138}$ Also, the Queen may appoint commissioners with such jurisdiction as is conferred on them by the 1963 Measure with respect to the review of findings of any such commission and also of the CECR. ${ }^{139}$ The CECR appears to have only sat twice since $1963 .{ }^{140}$

\section{Simplifying the Ecclesiastical Courts}

Moore said of a person reviewing the 1963 Measure, that it was:

designed very largely to simplify an outdated and complicated system, [however] he will find, in place of the old system, a new one in many respects so cumbersome and unpractical that it is doubtful whether, in some of its aspects, any attempt will be made to use it more than the one time necessary to convince even its authors of its unserviceability for many of the purposes for which it was designed. ${ }^{141}$

Prior to 1964, the civil appeal process was simple - from the consistory court to the provincial court. However, after that date, where the matter is a doctrinal (reserved) matter, it goes to the CECR, with a further right of appeal to a Commission. This is too unwieldy and complex (as Moore pointed out). Thus:

- Consideration should be given to abolishing consistory courts (as well as vicar-general's courts). Civil matters currently handled by the same should be handled by a chancellor - with a right to appeal to the High Court. The criminal jurisdiction currently handled by the consistory court should pass to the High Court;

- In doctrinal matters, the court of first instance should be an Ecclesiastical Court - with a right of appeal (final) to a Court of Ecclesiastical Appeal. It is likely such courts would sit rarely;

- The provincial courts, CECR and Commissions should be abolished. So too, the current right of appeal in non-doctrinal matters to the JCPC. ${ }^{142}$

In conclusion, it is asserted there should be a simplification of the ecclesiastical courts into an Ecclesiastical Court - as well as an Ecclesiastical Appeal Court - both handling doctrinal matters only. The High Court would

\footnotetext{
${ }^{134}$ Privy Council Appeals Act 1832. See also Halsbury, n 10, vol 10, para 807 and 1954 Report, n 119, p 25. Also Carter, n 47, pp 150-1.

For ecclesiastical appeal cases prior to 1832, see Ecclesiastical Appeals 1533-1832 (1868).

135 Halsbury, n 10, vol 10, para 805. See also 1963 Measure, s 1(3)(b) and 1954 Report, n 119, pp 53-6, 75-8.

1361963 Measure, s 5.

${ }^{137}$ Halsbury, n 10,vol 10, para 807. See also 1963 Measure, s 10.

1381963 Measure, s 1(2)(b) \& 1(3)(a). See also s 9.

139 Halsbury, n 10, vol 10, para 805. See also 1963 Measure, s 1(3)(c).

${ }^{140}$ Re St Michael and All Angels, Great Torrington [1985] 1 AE 993. Also, Re St Stephen Walbrook [1987] 2 AE 578.

${ }^{141}$ Moore, n 119, p 133.

142 The archdeaconary court never seems to have been formally abolished. See 1954 Report, n 119, p 27 ('a jurisdiction which is now never exercised and has recently been described as obsolete and beyond recall.'). This should also be done.
} 
handle civil matters - as well as cases of misconduct under the Clergy Discipline Act 1892. This would help integrate the ecclesiastical courts into the general court system.

\section{High Court}

The present jurisdiction of the High Court is as follows:

- The High Court has all jurisdiction (whether civil or criminal) conferred by the Senior Courts Act 1981 (the '1981 Act') and any other legislation. Also, such jurisdiction that it had prior to that Act including any jurisdiction conferred on a judge of the High Court by any statutory provision; ${ }^{143}$

- The original jurisdiction of the High Court is general - and it extends to all causes of action. However, its jurisdiction does not include certain mental health matters; ${ }^{144}$ nor where legislation provides otherwise. ${ }^{145}$ It may also depend on whether - in giving a particular certificate or decision - reasons have been stated; ${ }^{146}$

- The jurisdiction of the High Court is also appellate. ${ }^{147}$ Divisional courts, whose jurisdiction is mainly appellate, sit. ${ }^{148}$

However, in civil matters, some of the High Court's jurisdiction is allocated to the County Courts ('CC') with a reservation ('clawback') of some of the same:

(a) Under the High Court and County Courts Order 1991 proceedings (whether for damages or a specified sum) may not be started in the High Court unless the value of the claim is more than $£ 15,000$. Proceedings which include a claim for damages in respect of personal injuries - must not be started in the High Court unless the value is $£ 50,000$ or more. Monetary limits are also made in respect of probate matters, equity etc; 149

(b) Despite the above, jurisdiction over certain matters is reserved to the High Court viz (a) admiralty; (b) granting writs of habeus corpus (except where made by the parent (or guardian) of a minor re the custody of a minor); (c) granting applications for judicial review; (d) claims for damages in respect of a judicial act under the Human Rights Act 1998; (e) wardship jurisdiction; (f) restraining vexatious litigation; (g) libel and slander (unless the parties agree); (h) title to any toll, fair, market, franchise (unless the parties agree);

It is asserted that certain changes should be made to this jurisdiction in order to simplify matters and to remove anomalies, viz.

- The High Court should have (plenary) civil jurisdiction in all matters - save where that jurisdiction has been allocated by statute elsewhere. ${ }^{150}$ At present, the Crown Court has some (residual) civil jurisdiction (see 16). ${ }^{151}$ This should pass to the High Court;

- If so, there is no need to further specify the jurisdiction of the High Court. It will have plenary civil jurisdiction - leaving the County Court as the only other court having civil jurisdiction. ${ }^{152}$ Stating this will 'cut out' any jurisdictional uncertainty.

In conclusion, the High Court should have plenary jurisdiction and the County Courts' jurisdiction should be 'carved out' of that - not as presently done.

\footnotetext{
${ }^{143}$ Senior Courts Act, s 19(2). See also Halsbury, n 10, vol 10, para 607.

${ }^{144}$ Halsbury, n 10, vol 10, para 608. The Mental Health Act 1983, ss 93-113 have now been repealed (Mental Health Capacity Act 2005, s $66(1) \& 67(2))$.

${ }^{145}$ Halsbury, n 10, vol 10, para 319.

${ }^{146}$ Ibid, para $608, \mathrm{n} 38$.

${ }^{147}$ Ibid, para 606. British South Africa Co v Companhia de Mocambique [1893] AC 602.

148 Ibid, paras $605 \& 609$.

149 Halsbury, n 10, vol 10, para 608.

150 The Supreme Court is an appellate court and it has no original domestic jurisdiction (save that, it seems that the Queen can refer personal matters to it). As indicated in this previous article, the JCPC has statutory appellate jurisdiction in certain matters, which should be passed to the High Court and Supreme Court. Thus, any plenary civil jurisdiction of the High Court can only be affected by: (a) any civil jurisdiction of certain ancient courts (which, one is proposing, should be abolished, see 21); (b) any civil jurisdiction of the Crown and magistrates' courts (it is proposed this be transferred to the High Court); (c) any civil jurisdiction of the County Court (however, this jurisdiction is statutory); (d) any civil jurisdiction of tribunals (however, this jurisdiction is statutory).

${ }^{151}$ See 16.

${ }^{152}$ As noted in this article (see 16) any civil jurisdiction of the Crown Court should pass to the High Court and any civil jurisdiction of the magistrates' court should pass to the County Court (or to the High Court, if a three tier system is created, see 22).
} 


\section{High Court - Abolishing Divisions}

At present, the High Court has three divisions (Chancery, Queen's Bench, Family). ${ }^{153}$ The High Court was re-constituted under the 1981 Act. Thus, it is wholly statutory now.

- Save where the 1981 Act provides otherwise, the judges of the High Court have - in all respects equal power, authority and jurisdiction. ${ }^{154}$ Together, the divisions comprise one High Court ${ }^{155}$ and all jurisdiction belongs to all the divisions alike; ${ }^{156}$

- The 1981 Act also provides for the allocation of business between the divisions ${ }^{157}$ and an Order in Council may increase (or reduce) the number of divisions - as well as transfer the Patents, Admiralty or Commercial courts to different divisions. ${ }^{158}$

Within the Queen Bench are the following courts:

- Admiralty ${ }^{159}$

- Commercial; ${ }^{160}$

- Administrative; ${ }^{161}$

- Technology \& Construction; ${ }^{162}$

Within the Chancery division are the following courts:

- Bankruptcy;

- Companies;

- Patents. ${ }^{163}$

It is asserted that the Family Division should become the Family court. ${ }^{164}$ And - for the reasons given below the Chancery and the King's Bench divisions should be abolished, to be replaced by courts which contain their business.

In conclusion, it is asserted that the divisions within the High Court are unnecessary. They should be abolished. This practicality of this is now considered.

\subsection{Abolishing the Chancery Division}

To an outsider, the term 'chancery' means nothing. The 1981 Act assigns to this court all causes and matters relating to the:
(a) sale, exchange or partition of land - or the raising of charges on land;
(b) redemption - or foreclosure - of mortgages;
(c) execution of trusts;
(d) administration of estates of deceased persons;
(e) bankruptcy;

\footnotetext{
153 Senior Courts Act, s 5(1).

${ }^{154}$ Ibid, s 4 (3). See also Halsbury, n 10, vol 10, para 602.

155 Re Hastings (No 3) [1959] Ch 368.

156 Senior Court s Act 1981, s 5(3).

${ }^{157}$ Halsbury, n 10, vol 10, para 610. Provision is also made for the transfer of proceedings between the divisions of the High Court and between the High Court and a County Court.

${ }^{158}$ Ibid, s 7(1). See also Halsbury, n 2, vol 10, para 604.

${ }^{159}$ Halsbury, n 10, para 615 'There is constituted as part of the [QBD] an Admiralty Court to take admiralty business, that is to say causes and matters assigned to the [QBD] and involving any exercise of the High Court's Admiralty jurisdiction or jurisdiction as a prize court.' See also para $606, \mathrm{n} 5$.

${ }^{160} \mathrm{Ibid}$, 'There is also constituted as part of the [QBD] a Commercial Court to take such causes and matters as may in accordance with rules of court be entered in the commercial list.'

${ }^{161}$ Ibid, para 614 'The business of, and procedure in, the Administrative Court, which is mainly concerned with judicial review, statutory appeals and applications, habeus corpus and extradition...'

162 Ibid, para 616 'There is now constituted a Technology and Construction Court to take [its] business (formerly known as 'official referee's business').'

${ }^{163}$ Ibid, para 612 'There is constituted a patents court to take such proceedings relating to patents as are within the jurisdiction conferred on it by the Patents Act 1977 and such other proceedings relating to patents as may be prescribed.'

${ }^{164}$ For its present jurisdiction, see Senior Courts Act 1981, s 26.
} 
(f) dissolution of partnerships - or the taking of partnership or other accounts;

(g) rectification, setting aside or cancellation of deeds - or other instruments in writing;

(h) probate business - other than non-contentious or common form business;

(i) patents, trade marks, registered designs, copyright or design rights;

(j) appointment of a guardian of a minor' estate;

(k) all causes and matters involving the exercise of the jurisdiction of the High Court under the enactments relating to companies;

(k) certain statutory appeals. ${ }^{165}$ (italics supplied)

One of the merits of the present individual courts of the High Court is that: (i) their name describes their function in a way that the public can understand; (ii) it enables each court to develop its own rules - reducing the great 'wodge' of civil procedure generally. It is asserted the Chancery Division be abolished and that its jurisdiction if not presently allocated to specific courts - be divided out to other courts. Thus,

- There should be a Land and Probate Court, ${ }^{166}$ which deals with all matters relating to land. It will include the matters italicised above. Certain land tribunals could also be merged into it, if possible; ${ }^{167}$

- It would seem all other Chancery business anyway is being handled by the current courts (Bankruptcy, Companies, Patents). Any residue could be allocated to the Commercial Court. In any case, it may be noted there is a power to assign business to specially nominated judges under the 1981 Act. ${ }^{168}$

In conclusion, the Chancery Division should be abolished and its work allocated to specific courts.

\subsection{Abolishing the Queen's Bench Division}

This court needs to change its name from time to time - depending on the change in sex of the sovereign. The 1981 Act assigns to it:

- Applications for writs of habeus corpus - except for applications made by a parent (or guardian) of a minor for such a writ concerning the custody of the minor; ${ }^{169}$

- Applications for judicial review;

- All causes and matters involving the Admiralty jurisdiction of the High Court - or its jurisdiction as a prize court;

- All causes and matters entered into the commercial list;

- The assignment of statutory appeals and applications to the Queen's Bench division and the Civil Procedure Rules. ${ }^{170}$

As Halsbury notes, the jurisdiction of this court is much wider than as stated. However, like the term 'chancery' the words 'queen's bench' do not convey any sense of what this division does; nor its jurisdiction. It is asserted this division should also be abolished.

- Any criminal jurisdiction of the Queen's Bench division and the civil courts should be transferred to the Crown Court (the civil courts have jurisdiction to make orders for the seizure (and confiscation) of money and other property under the control of defendants in criminal cases; ${ }^{171}$ also, applications for habeus corpus in the criminal context);

- Most other Queen's Bench business anyway is being handled by other courts. Thus, judicial review is handled by the Administrative Court, admiralty by the Admiralty Court and habeus corpus in respect of applications made by a parent (or guardian), by the Family divison (which, one asserts,

\footnotetext{
${ }^{165}$ Halsbury, n 10, vol 10, para 611.

${ }^{166}$ For probate, see Senior Courts Act 1981, s 25.

${ }^{167}$ For the Land Tribunal, see Halsbury, n 10, vol 10, para 203 et seq. For the Conveyancing Appeals Tribunal, ibid, para 819.

${ }^{168}$ Halsbury, n 10, vol 10, para 618.

169 Senior Courts Act 1981, sch 1 para 2 (a).

${ }^{170}$ Halsbury, n 10, vol 10, para 613. See also para 310

171 Ibid, para 310. See also Criminal Justice Act 1988, pt 6 and Drug Trafficking Act 1994. See Hanbury (1960), p 150 'By section 11 of the Administration of Justice (Miscellaneous Provisions) Act 1938, the criminal jurisdiction of the King's Bench Division of the High Court has been reduced almost to vanishing point.'
} 
should become a court). Any other jurisdiction should pass to the other courts of the High Court. In particular, the Commercial Court.

In conclusion, the High Court should not comprise any divisions - only 9 courts - including a new Land and Probate court.

\subsection{Admiralty Court to Become Transport Court}

The current jurisdiction of the admiralty court is - mainly as a result of historical reasons - narrowly circumscribed. Thus, the 1981 Act, ss 20-4 lay down a limited jurisdiction which also makes little sense. For example, the admiralty court has in rem jurisdiction in respect of aircraft only in respect of: salvage, towage (waterbourne aircraft, excluding Crown aircraft) and pilotage (waterbourne aircraft, excluding Crown aircraft). However, in practice, the pilotage or towage of aircraft does not now occur, and the salvage of aircraft is exceedingly rare. ${ }^{172}$ There is no reason why this court should not deal with aviation matters generally.

It is asserted the Admiralty court should become a Transport court (like Germany has). It should handle all shipping, aviation, railways and road cases - save where statute provides otherwise. ${ }^{173}$ Thus, there would be no need for the Senior Courts Act 1981, ss 20-4.

In conclusion, the High Court should have plenary jurisdiction over all civil matters. The divisions of the HC (Chancery, Queen's Bench and Family) should be abolished - since they do not mean anything and are not necessary. The present 8 courts (Admiralty, Commercial, Administrative, Technology \& Construction, Bankruptcy, Company, Patents, Family) should be joined by a Land and Probate Court. The Admiralty court should expand to become a Transport Court.

\section{Crown Court - Transferring Criminal Jurisdiction to It}

The Crown Court was established by the Courts Act 1971.

- It is a single indivisible court, a superior court of record with jurisdiction which includes all powers and duties as were exercisable (or fell to be performed) by it prior to 1 January $1982 ;{ }^{174}$

- In relation to: the attendance and examination of witnesses, contempt of court, the enforcement of its orders and other matters incidental to its jurisdiction - it has the same powers, rights, privileges and authority as the High Court;

- The jurisdiction (and powers) of the Crown court may be exercised by any High Court judge, circuit judge or recorder, sitting with (or without) justices of the peace. ${ }^{175}$

The Crown Court has exclusive jurisdiction in respect of all proceedings brought by way of indictment. ${ }^{176}$ The Crown Court is subject to the supervisory jurisdiction of the High Court where the 1981 Act, ss 28 and 29 so grants. ${ }^{177}$ In particular, s 28 provides that:

any order, judgment or other decision of the Crown Court may be questioned by any party to the proceedings, on the ground that it is wrong in law or is in excess of jurisdiction, by applying to the Crown Court to have a case stated by that court for the opinion of the [High Court]

This does not apply to a judgment (or decision) of the Crown Court relating to trial on indictment. Nor to decisions of that court under the Gaming Act 1968 (Gambling Act 2005) or to the Local Government (Miscellaneous Provisions) Act 1982. ${ }^{178}$

The civil courts also exercise some criminal jurisdiction in that they have jurisdiction to make orders for the seizure - and confiscation - of money and other property under the control of defendants in criminal cases. ${ }^{179}$ This criminal jurisdiction should be transferred to the Crown Court.

In conclusion, any criminal jurisdiction of the civil courts should be transferred to the Crown Court.

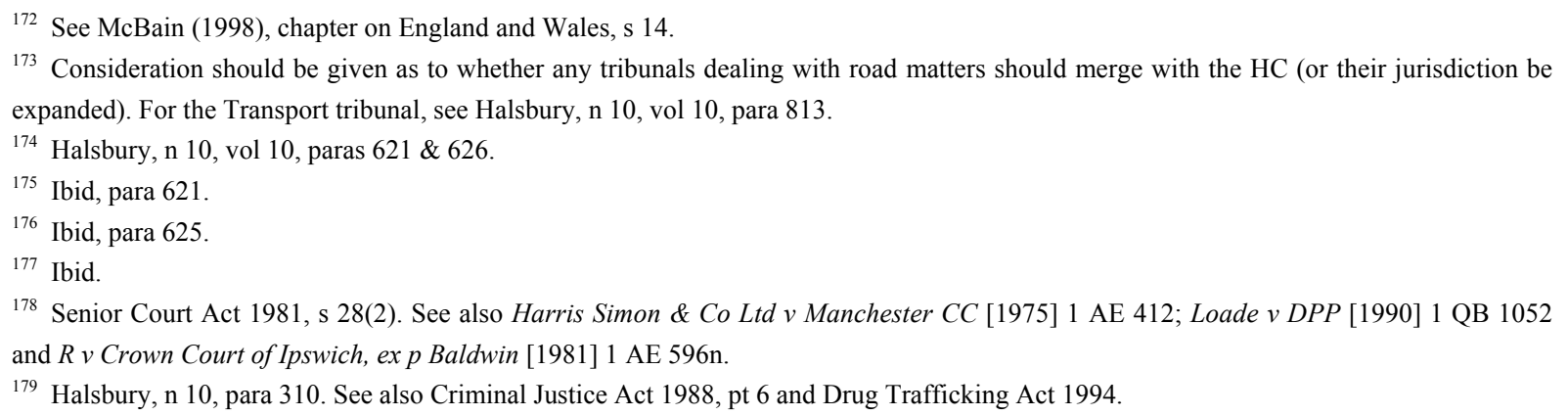




\section{Crown Court - Transferring Its Civil Jurisdiction to High Court}

Halsbury notes that:

The original civil jurisdiction of the former courts of quarter sessions, although nowhere clearly defined, probably included, historically, those administrative functions which were transferred to local authorities by the Local Government Acts, as well as those functions of justices which were exercised, latterly, by magistrates' courts committees, or by other committees to which justices were appointed by quarter sessions. Special provision has been made for the exercise of powers of appointment to such committees since the establishment of the Crown Court. The Courts Act 1971 transferred to the Crown Court the remaining original civil jurisdiction, which is now concerned with the repair of highways and certain matters concerning firearms certificates. ${ }^{180}$

Halsbury also notes that the extent of the original civil jurisdiction transferred to the Crown Court is unclear since it probably included a number of provisions in local Acts which conferred an original jurisdiction on the courts of quarter sessions. However, today, it would seem to likely to only cover jurisdiction in relation to:

- Firearms Act 1968, s 21(6),(7), Sch 3 Pt $1^{181}$ (person applying for the removal of a prohibition on possessing a firearm);

- Highways Act 1980, s 6(2) (proceedings for an order to repair a highway).

There would seem no good reason why the latter - at least - should not pass to the County Court and the former to the High Court. Halsbury also states:

In addition to the jurisdiction to hear appeals from magistrates' courts, the Crown court has jurisdiction to entertain appeals from the decisions of local and other authorities in certain matters. For example, an appeal lies against certain decisions of a police authority with regard to police pensions, and against decisions of a licensing authority in connection with film exhibitions. Certain decisions of a chief officer of police in relation to firearms certificates and the registration of firearms dealers may also be the subject of an appeal to the Crown Court. ${ }^{182}$

The criminal courts may also make restitution (and compensation) orders against convicted persons. ${ }^{183}$ There is no especial reason why the Crown Court should exercise civil jurisdiction and, to make the court system more intelligible, there is good reason why the High Court should have plenary jurisdiction in civil matters (and the Crown Court that in criminal matters).

It is asserted that all civil jurisdiction of the Crown Court should pass to the High Court.

\section{Merging High and Crown Courts}

It has previously been suggested that the High Court should have plenary civil jurisdiction and that the Crown Court plenary criminal jurisdiction. This solves, at one stroke, problems of jurisdiction at their level. However, one would also suggest that the High Court and the Crown Court be merged.

- $\quad$ Thus, there would only be one court handling all civil matters. This would simplify matters greatly - not least because the HC would then comprise 10 courts ( 9 civil and one criminal) - all with intelligible names which could establish their own rules. This would be of help to barristers since many of them, anyway, would only practice before that court;

- If the High Crown and Crown Court were merged then the High Court would have two divisions civil and criminal - each with plenary jurisdiction. This would replicate the Court of Appeal which is so divided. This would radically simplify the law, rationalise the court system, make it more intelligible and, indeed, optimise the prospect of speedy justice.

In conclusion, the High Court and Crown Court should be merged.

\section{County Courts - Nature \& Jurisdiction}

The county courts are creatures of legislation - the County Courts Act 1984 (the '1984 Act'). ${ }^{184}$ This Act divides England and Wales into districts (the City of London has its own county court) ${ }^{185}$ with the holding of a County

${ }^{180}$ Ibid, para 630.

181 Ibid.

182 Ibid, para 629.

183 Ibid, para 310. Powers of Criminal Courts (Sentencing) Act 2000, ss 130, 148.

184 Ibid, para 701.

185 The Mayor's and City of London court. See Halsbury, n 10, vol 10, para 708. 
Court for each district at one - or more - places in that district. The districts are determined in accordance with directions given by (or on behalf of) of the Lord Chancellor. Currently, there are some 240 County Courts. Some have assigned to them particular - as well as general - jurisdiction, viz. they also comprise:

- Divorce county courts;

- Race relations county courts;

- Insolvency Act county courts;

- Mercantile claims county courts;

- Technology \& Construction claims county courts;

- Road traffic penalties county court (Northampton county court). ${ }^{186}$

Halsbury provides that - under the 1984 Act and - subject to the monetary limits set out in the High Court and County Courts Jurisdiction Order 1991 (and the practice directions supplementing the Civil Procedure Rules which regulates the commencement of proceedings) - a County Court has jurisdiction:

to entertain nearly all types of claims which may be the subject of civil proceedings in the High Court. Thus, within those limits and subject to the practice direction and to the exceptions stated subsequently, it may hear and determine any claim founded on contract or tort, ${ }^{187}$ any claim for the payment of money recoverable by statute, ${ }^{188}$ any claim for the recovery of land, ${ }^{189}$ and any of the classes of equity and probate proceedings mentioned in the 1984 Act. ${ }^{190}$

It may also hear claims where it has jurisdiction by virtue of a special statute. ${ }^{191}$ Where the High Court has jurisdiction, the County Court does not. ${ }^{192}$ Nor where a different tribunal is specified. ${ }^{193}$

In short, the County Court handles the more minor civil cases - in financial terms or complexity.

\section{County Courts - Reformation}

Various steps should be taken to simplify the County Courts and make them more intelligible to the public:

- County Court is a Misnomer. The term 'County Court' does not actually mean anything since the County Courts are not allocated one per county. There is no need - anyway - to link them to counties. To the general public, the term 'Civil Court' would have much more meaning;

- Expanding Districts into Regions. Consideration should be given to expanding the districts in which County Courts operate. The whole intention should be able to keep the courts fully occupied with good case management that allows cases to be 'drawn in' from a wider area. Thus, considerations should be given to adopting regions (as opposed to districts) having regard also to the distance people have to travel. That said, most people would probably prefer to have their case dealt quickly - and go a longer distance - than to wait;

- $\quad$ Reducing Number of County Courts. Consideration should also be given to reducing the number of County Courts, making them more manageable to handle. Further, all County Courts should be located in the same building as Crown and Magistrates courts. Indeed, the same court should be available, where possible. This will reduce administration costs and improve access for the public;

- $\quad$ Aligning Courts. The courts of the High Court should be reflected in the County Court (ie. 9 courts with the same specialities, but at a lesser level of financial worth or complexity). Further, the names of the High Court and the County Court should be harmonised. For example, the County Court has a Mercantile Claims court (see 18). However, in the High Court, this is called the 'Commercial Court'. Thus, mercantile courts should be called commercial courts, with appeals to the High Court, Commercial Court. Further, are County Courts, Race Relations courts (see 18) really needed ? Can they not be dispensed with ?

- $\quad$ Removing Exclusive High Court Jurisdiction - Tolls \& Franchise. At present, the High Court reserves to itself jurisdiction in respect of claims relating to tolls and franchises. Such claims are

${ }^{186}$ Halsbury, n 10, vol 10, para 713.

${ }^{187}$ Ibid, paras $710 \& 712$.

${ }^{188}$ Ibid, paras $710 \& 713$.

189 Ibid, paras $710 \& 715$.

${ }^{190}$ Ibid, paras 718 \& 719.

191 Ibid, para 721.

192 Ibid, para 722.

193 Ibid, para 723. 
now likely to be very rare, since few franchises now exist. ${ }^{194}$ Also, few tolls. There is no good reason why the County Court should not deal with the same;

- Granting Sole Jurisdiction to the High Court - Mining. The High Court should have sole jurisdiction to deal with mining claims since this is a complex area. ${ }^{195}$ In this, it would be the same as the Admiralty court.

In conclusion, the county courts should re-named 'Civil Court's', their number reduced and they should have jurisdiction in a region - not a district. Their jurisdiction will be 'carved out' from that of the High Court. They should replicate the 9 courts of the High Court's (see above). There should be separate sets of rules for these 9 courts - reducing the current 'wodge' of civil jurisdiction rules.

\section{Magistrates' Courts - Passing Civil Jurisdiction to County Courts}

As well as exercising criminal jurisdiction, these magistrates' courts exercise civil jurisdiction. Thus, Halsbury states:

The civil or quasi-civil jurisdiction of magistrates' courts includes jurisdiction as to the summary recovery of certain civil debts, family proceedings, the adoption and care of children, the care of aged and infirm persons, the enforcement of council tax and non-domestic rates, and driving tests, and many other matters. ${ }^{196}$

The position as to magistrates' courts could be much improved. It is asserted that:

- The civil jurisdiction of magistrates should pass to the County Courts;

- The concept of a magistrates' court does not mean much to the general public. It would be much better to call it the 'Criminal Court' (just as the County Court should be called the 'Civil Court');

- At present, magistrates - in most instances - are laymen. In modern times, it would ensure a more professional standard of justice - as well as a likely speedier one - if the system of laymen magistrates ended and professional lawyers were employed.

In conclusion, magistrates' courts should only handle criminal matters (civil jurisdiction passing to County Courts). Further, they should be professionalised.

\section{Obsolete Courts, Courts Of Record, Puisne Judges}

There are a large number of obsolete courts. This has been considered in detail in a previous article and so it will not be further considered in this article. ${ }^{197}$ Further, two other legal concepts are not required and should be abolished - courts of record and puisne judges.

- Courts of Record. The concept of a 'court of record' is not well understood. Indeed, no one knows what it really meant anyway. ${ }^{198}$ However, today, it is generally treated as meaning that the court has the power to imprison and fine. Assuming all the obsolete courts referred to in the Appendix are abolished, legislation can simply provide that the Supreme Court, Court of Appeal, High Court, Crown Court, County Court and Magistrates' courts have such power. ${ }^{199}$ Thus, the concept of a 'court of record' can be avoided and it will - doubtless - become obsolete; ${ }^{200}$

- Pusine Judges. Another term which serves only to confuse is 'puisne' (inferior) judge. Under the Senior Courts Act 1981, it refers to High Court judges who do not hold the office of: (a) Lord Chief

\footnotetext{
194 See McBain (2011a), vol 32, issue 3, pp 275-315.

195 The Barmote courts handle lead mining in Derbyshire. However, they are obsolete. The Cornwall county courts have jurisdiction under the Stannary Acts. However, this stannary jurisdiction is obsolete. Further, there are a number of old mining customs in relation to Cornwall, Devon, Derbyshire and the Forest of Deaan, all of which are obsolete. See generally, McBain (2012).

196 Ibid, para 679. For family proceedings, see para 739.

${ }^{197}$ See McBain (2012).

${ }^{198}$ Halsbury, n 10, vol 10, para 308 'In the case of courts not expressly declared to be courts of record, the answer to the question whether a court is a court of record seems to depend in general upon whether it has power to fine or imprison, by statute or otherwise, for contempt of itself or other substantive offences; if it has such power, it seems that it is a court of record.'

199 In 22, one asserts that the Crown, County and Magistrates' courts should be merged into the High Court.

${ }^{200}$ By statute, those in italics are stated to be courts of record. So too, the Court Martial Appeal Court, Employment Appeal Tribunal, Special Immigration Appeals Commission. See Halsbury, n 10, vol 10, para 308. The Coroner's court is also a court of record. Halsbury, $\mathrm{n}$ 10, para 583, says that 'For some purposes at least it seems that it [ie. the Magistrates' courts] is a court of record. Power is conferred on magistrates' courts to punish contempts in the face of the court.' This should be clarified. Since these courts, today, can imprison, fine and punish for contempt, it would seem that they are (and should be treated as) courts of record.
} 
Justice; (b) President of the Family Division; (c) Chancellor of the High Court; (d) Senior Presiding Judge; (e) Vice-President of the Queen's Bench division. ${ }^{201}$ However, there would seem no need for the term and, to the general public and lawyers, it would seem easier to refer to them as High Court judges. The latter also are termed 'Justices of the High Court'. However, the more modern term ' $j u d g e$ ' is commonly used and, thus, consideration should be given to simply referring to all and one as 'Judges of the High Court.'

\section{Creating a Three Tier System}

All the previously mentioned changes to the court system would improve it - removing anomalies and merging courts. However, in order to really place the court system on a more efficient and business like footing, it is asserted the lower courts should be merged. At present, the English court system is - at least - a four tier one.

- Besides the Supreme Court and the Court of Appeal - which are appeal courts - there are also the High Court (which sometimes also exercises supervisory jurisdiction over the Crown Court) and the Crown Court. There are also the County and Magistrates' courts;

- Much of this has arisen out of the gradual consolidation of the English court system through the centuries. Further, there are now appeals possible to other courts - such as the European Court and the European Court of Human Rights.

The effect is to create a complex and costly system, which is not very efficient or intelligible.

- It is asserted the lower court system needs radical reform. As well as the Crown Court being merged into the High Court, it is asserted the County and Magistrates' courts should be merged into the High Court. Thus, there would be just one basic court - the High Court. And two appeal courts - the Supreme Court and the Court of Appeal;

- This unitary High Court would have a criminal and a civil division. Both would have plenary jurisdiction in their respective spheres;

- There would be High Court - and Deputy High Court - judges. The latter would handle the matters currently handled by the County and Magistrates' courts. This would be more rational - since the complexity of a matter would not relate to the type of court but to the experience of the judge.

The overall effect of all this would be to hugely simplify the court system - removing one layer of courts (the County and Magistrates' courts) and merging another (the Crown Court) into the High Court. Thus, the High Court would have plenary criminal and civil jurisdiction (as two distinct streams).

- All cases would be triable by High Court judges - their deputies would try lesser civil cases (and crimes) with appeals to divisional courts of the High Court; ${ }^{202}$

- The procedure for the High Court, criminal division could be set out in one set of rules. The procedure for the 9 civil courts comprising the High Court, civil division would also be set out in rules for each of those courts - breaking the current 'wodge' of civil procedure rules and regulations as well as recognising that lawyers would be unlikely to practice in more than one or two of the 9 civil courts.

In conclusion, the Crown, County and Magistrates's courts should be merged into the High Court.

\section{Conclusion}

The current court system is not economically optimal. Nor is it understood by lawyers and laymen alike. It is replete with anomalies and unnecessary courts. The purpose of this article is to argue that the English court system should be improved. Also, that there should be a phased transition to a 3 tiered court system, viz

- Supreme Court (containing the Judicial Committee of the Privy Council) ${ }^{203}$

- Court of Appeal (criminal and civil divisions, containing the Court Martial Appeal Court); ${ }^{204}$

- High Court (criminal and civil divisions)

The High Court would comprise 10 courts - one of which is a criminal court. High Court judges would handle all cases, where desired. Deputy High Court judges would handle the current County and Magistrates' courts

\footnotetext{
201 Senior Courts Act 1981, s 4 (1).

202 In a three tier system, it is probably better to abolished divisional appeals and let them go to the Court of Appeal.

203 This will not merge the two courts as such. However, there is nothing to prevent legislation stating 'The Supreme Court shall sit as the Judicial Committee of the Privy Council as and when required.'

204 As previously noted, the Court Martial Appeal Court handles very few appeals each year in any case (15 in 2010 and 18 in 2011 ).
} 
material. There would only be two types of judges (thus, recorders, circuit judges etc would disappear). This simplification of the court system and judicial titles would speed up - and professionalise - the resolution of cases.

Finally, for the benefit of the public (and lawyers), the new court system would be displayed online on a website 'The Court System'. It would have an icon for each of the courts in the system and - like the current website for the JCPC - it would set out the judges of each court, its rules and procedure, how to find the court etc.

\section{References}

Adair, E. R. (1924). Sources for the History of the Council in the $16^{\text {th }}$ and $17^{\text {th }}$ Centuries. (Historical Association)

Baldwin, J. F. (1913). The King's Council in England during the Middle Ages. Oxford.

Beauchamp, J. J. (1892). The Jurisprudence of the Privy Council. Montreal.

Bentwich, N. (1937). Practice of the Privy Council in Judicial Matters (3rd ed.). Sweet \& Maxwell.

Blackstone, W. (1765-9). Commentaries on the Laws of England (1st ed.) Oxford: Clarendon Press (University of Chicago Press, rep 1979).

Burge, W. (1841). Observations on Supreme Appellate Jurisdiction as exercised by Queen in Council and House of Lords. Saunders \& Benning.

Carter, A. T. (1944). A History of the English Courts (7th ed.). Butterworths.

Coote, H. C. (1847). The Practice of the Ecclesiastical Courts. Butterworth.

Coote, H. C. (1868, sup 1869). Admiralty Practice with the Practice of the Privy Council relating thereto (2nd ed.).

Dicey, A. V. (1887). The Privy Council. Oxford.

Edwards, E. (1853). Ecclesiastical Jurisdiction.

Finlason, W. F. (1878). The History, Constitution and Character of the Judicial Committee of the Privy Council considered as a judicial tribunal, especially in Ecclesiastical Cases. Stevens.

Fitzroy, A. (1928). History of the Privy Council. J Murray.

Fuller, M. J. (1865). Court of Final Appeal; or, the Appellate Jurisdiction of the Crown in Ecclesiastical Cases (reprint Gale, 2010). J Murray.

Hale, M. (1971). The History of the Common Law of England. University of Chicago Press.

Halsbury. Laws of England (4th ed.).

Halsbury. Statutes of England (4th ed.).

Hanbury, H. G. (1960). English Courts of Law (3rd ed.). Oxford University Press.

Hemmant, M. (1945). Select Cases in the Exchequer Chamber before all the Justices of England, vol 2 (1461-1509). Selden Society Reports.

Hill. (2007). Ecclesiastical Law (2007). Oxford University Press.

Holdsworth, W. (2003). A History of English Law (Sweet \& Maxwell, reprint 2003).

Howell, P. A. (1970). The Judicial Committee of the Privy Council, 1833-1876. Cambridge University Press.

Janis, M. W. et al. (2008). European Human Rights Law (3rd ed.). Oxford University Press.

Joyce, J. W. (1881). The Sword and the Keys (2nd ed.). London: English Church Union.

Kiralfy, A. K. R. (1957). A Sourcebook of English Law. London: Sweet \& Maxwell.

Leadam I. S., \& Baldwin J. F. (1918). Select Cases before the King's Council 1243-1482. Selden Society Reports.

Lord Haldane. (1922). The Work for the Empire of the Judicial Committee of the Privy Council. Cambridge Law Journal. http://dx.doi.org/10.1017/S0008197300102600

Macpherson, W. (1873). Practice of the Judicial Committee of Her Majesty's Most Honourable Privy Council (2nd ed.). Henry Sweet.

Macqueen, J. F. (1842). Appellate Jurisdiction of the House of Lords and Privy Council. A Maxwell. 
McBain, G. S. (1998). Aircraft Liens and Detention Rights (Sweet \& Maxwell, looseleaf).

McBain, G. S. (2011a). Abolishing Some More Obsolete Crown Prerogatives - Part 2. Liverpool Law Review (also online). http://dx.doi.org/10.1007/s10991-011-9090-4

McBain, G. S. (2011b). Abolishing 'High Crimes and Misdemeanours' and the Criminal Processes of Impeachment and Attainder. Australian Law Journal.

McBain, G. S. (2011c). Modernising the Monarchy in Legal Terms: Part 2. King's Law Journal.

McBain, G. S. (2012). Abolishing some Obsolete Courts. Coventry Law Journal.

Moore, E. G., \& Briden, T. (1985). Moore's Introduction to English Canon Law (2nd ed.). Mowbray.

Paget, J. (1854). Ecclesiastical Courts. Thomas Blenkarn.

Palmer, J. (1831, sup 1834). Practice on Appeals from the Colonies to the Privy Council. Saunders \& Benning.

Palmer, R. (Lord Selborne). (1891). Judicial Procedure in the Privy Council. London. Macmillan.

Percy, E. (1907). The Privy Council under the Tudors. Oxford.

Polden, P. (2010). The Judicial Roles of the House of Lords and Privy Council 1820-1914. In W. Cornish (Ed.), Oxford History of the Laws of England (Vol. 11). Oxford.

Pollock, F., \& Maitland, F. W. (1968). The History of English Law before the time of Edward I. Cambridge University Press.

Preston, T. (1900). A Manual stating the Practice and Procedure in Colonial and Indian Appeals before of the Lords of the Judicial Committee of ...the Privy Council. Eyre \& Spottiswoode.

Rankin, G. C. (1939). The Judicial Committee of the Privy Council. Cambridge Law Journal. http://dx.doi.org/10.1017/S0008197300127539

Salford, F., \& Wheeler, G. (1901). Practice of the Privy Council in Judicial Matters in Appeals.

Smith, C. (2008). Ridsdale v Clifton: Representations of the Judicial Committee of the Privy Council in Ecclesiastical Appeals. King's Law Journal.

Smith, C. (n. d.). An Introduction to the Judicial Committee of the Privy Council. Retrieved from www.plymouth.ac.uk

Stephen, J. F. (1883). A History of the Criminal Law of England. Macmillan \& Co.

Stevens, R. (1964). The Final Appeal: Reform of the House of Lords and Privy Council 1867-1876. Law Quarterly Review.

Stubbs, W. (1966). Select Charters (9th ed.). Oxford.

Sweet \& Maxwell. (1957). A Legal Bibliography of the British Commonwealth of Nations. Sweet \& Maxwell.

Swinfen, D. B. (1974). Henry Brougham and the Judicial Committee of the Privy Council. Law Quarterly Review.

Swinfen, D. B. (1987). Imperial Appeal: the Debate on the Appeal to the Privy Council, 1833-1986. Manchester.

Tout, J. F. (1914). The Place of the Reign of Edward II in English History. Manchester.

Tristam, T. H. (1893). The Principal Judgments delivered in the Consistory Courts of London etc(1872 to 1890).

Turner, E. R. (1927-8). The Privy Council of England in the $17^{\text {th }}$ and $18^{\text {th }}$ Centuries. Baltimore.

Wheeler, G. (1893). Privy Council Law. Appeals from 1876-91. Stevens.

\section{Copyrights}

Copyright for this article is retained by the author(s), with first publication rights granted to the journal.

This is an open-access article distributed under the terms and conditions of the Creative Commons Attribution license (http://creativecommons.org/licenses/by/3.0/). 